\title{
Article \\ Methyl 2-Halo-4-Substituted-5-Sulfamoyl-Benzoates as High Affinity and Selective Inhibitors of Carbonic Anhydrase IX
}

\author{
Audrius Zakšauskas ${ }^{1}$, Edita Čapkauskaitè ${ }^{1}$, Vaida Paketurytè-Latvè ${ }^{1}$, Alexey Smirnov ${ }^{1}$, Janis Leitans ${ }^{2}$, \\ Andris Kazaks ${ }^{2}$, Elviss Dvinskis ${ }^{2}{ }^{(D}$, Laimonas Stančaitis ${ }^{1}$, Aurelija Mickevičiūtè ${ }^{1}$, Jelena Jachno ${ }^{1}$, \\ Linas Jezepčikas ${ }^{1}$, Vaida Linkuvienè ${ }^{1}$, Andrius Sakalauskas ${ }^{1}$ D, Elena Manakova ${ }^{3}$, Saulius Gražulis ${ }^{3}$, \\ Jurgita Matuliené ${ }^{1}$, Kaspars Tars ${ }^{2}$ and Daumantas Matulis ${ }^{1, *(D)}$
}

1 Department of Biothermodynamics and Drug Design, Institute of Biotechnology, Life Sciences Center, Vilnius University, Saulètekio al. 7, LT-10257 Vilnius, Lithuania; audrius.zaksauskas@bti.vu.lt (A.Z.); edita.capkauskaite@bti.vu.lt (E.Č.); vaida.paketuryte@gmc.vu.lt (V.P.-L.); alexeyus1@gmail.com (A.S.); laimonas.stancaitis@gmc.vu.lt (L.S.); aurelija.mickeviciute@bti.vu.lt (A.M.); jelena.jachno@bti.vu.lt (J.J.); linasje@gmail.com (L.J.); linkuviene.vaida@gmail.com (V.L.); andrius.sakalauskas@gmc.vu.lt (A.S.); jurgita.matuliene@bti.vu.lt (J.M.)

2 Latvian Biomedical Research and Study Centre, Ratsupites 1 k-1, LV-1067 Riga, Latvia; janis.leitans@biomed.lu.lv (J.L.); andris@biomed.lu.lv (A.K.); elviss.dvinskis@protonmail.com (E.D.); kaspars@biomed.lu.lv (K.T.)

3 Department of Protein-DNA Interactions, Institute of Biotechnology, Life Sciences Center, Vilnius University, Saulètekio al. 7, LT-10257 Vilnius, Lithuania; elena.manakova@bti.vu.lt (E.M.); saulius.grazulis@bti.vu.lt (S.G.)

* Correspondence: daumantas.matulis@bti.vu.lt

check for updates

Citation: Zakšauskas, A.; Čapkauskaitè, E.; Paketurytè-Latvè,

V.; Smirnov, A.; Leitans, J.; Kazaks, A.; Dvinskis, E.; Stančaitis, L.;

Mickevičiūtè, A.; Jachno, J.; et al. Methyl 2-Halo-4-Substituted-5Sulfamoyl-Benzoates as High Affinity and Selective Inhibitors of Carbonic Anhydrase IX. Int. J. Mol. Sci. 2022, 23, 130. https://doi.org/10.3390/ ijms23010130

Academic Editor: Christophe Morisseau

Received: 24 November 2021 Accepted: 18 December 2021 Published: 23 December 2021

Publisher's Note: MDPI stays neutral with regard to jurisdictional claims in published maps and institutional affiliations.

Copyright: (c) 2021 by the authors Licensee MDPI, Basel, Switzerland. This article is an open access article distributed under the terms and conditions of the Creative Commons Attribution (CC BY) license (https:// creativecommons.org/licenses/by/ $4.0 /)$.
Abstract: Among the twelve catalytically active carbonic anhydrase isozymes present in the human body, the CAIX is highly overexpressed in various solid tumors. The enzyme acidifies the tumor microenvironment enabling invasion and metastatic processes. Therefore, many attempts have been made to design chemical compounds that would exhibit high affinity and selective binding to CAIX over the remaining eleven catalytically active CA isozymes to limit undesired side effects. It has been postulated that such drugs may have anticancer properties and could be used in tumor treatment. Here we have designed a series of compounds, methyl 5-sulfamoyl-benzoates, which bear a primary sulfonamide group, a well-known marker of CA inhibitors, and determined their affinities for all twelve CA isozymes. Variations of substituents on the benzenesulfonamide ring led to compound $4 \mathbf{b}$, which exhibited an extremely high observed binding affinity to CAIX; the $K_{d}$ was $0.12 \mathrm{nM}$. The intrinsic dissociation constant, where the binding-linked protonation reactions have been subtracted, reached $0.08 \mathrm{pM}$. The compound also exhibited more than 100 -fold selectivity over the remaining CA isozymes. The $\mathrm{X}$-ray crystallographic structure of compound $3 \mathbf{b}$ bound to CAIX showed the structural position, while several structures of compounds bound to other CA isozymes showed structural reasons for compound selectivity towards CAIX. Since this series of compounds possess physicochemical properties suitable for drugs, they may be developed for anticancer therapeutic purposes.

Keywords: methyl 5-sulfamoyl-benzoate; human carbonic anhydrase; intrinsic binding thermodynamics; enzyme inhibitor; X-ray crystallography; fluorescent thermal shift assay

\section{Introduction}

Low-molecular-weight compounds that strongly interact and inhibit the disease target enzymes may be developed as therapeutic drugs. The carbonic anhydrase (CA) family (CA EC 4.2.1.1), consisting of twelve catalytically active human isozymes, performs the catalysis of reversible hydration of $\mathrm{CO}_{2}$ into bicarbonate and acid protons. These enzymes participate in numerous physiological processes such as $\mathrm{pH}$ regulation and carbon metabolism and are also related to various diseases and conditions such as glaucoma, epilepsy, cancer, edema, osteoporosis, and obesity [1,2]. Since it has been observed that CAIX isozyme is highly 
overexpressed in numerous cancers, it has been postulated that compounds inhibiting CAIX may possess the anticancer activity and may be used in tumor treatment [3-5].

Many CA inhibitors have been synthesized bearing flexible tails capable of finding an energetically favorable position in several CA isozymes, thus losing selectivity [6,7]. We have attempted to design inhibitors with a restrained position of the ring and two functional groups attached to the benzenesulfonamide [8-10]. This approach helped design inhibitors selective for CAVII, CAIX, CAXII, and CAXIV.

The introduction of a halogen in the ortho- position relative to sulfonamide constrained the benzenesulfonamide ring in a stable position in the CA active site. Additional substituents in the meta- and para-positions provided additional leverage for increased affinity and selectivity [11-13]. However, these compounds did not fully exploit differences in the CA active site and did not reach sufficient selectivity.

The isozymes CAIX and CAXII exhibit slightly more opened active site entrance than CAI and CAII because, at the entrance of the binding pocket, CAIX has Val131, and CAXII has Ala131, while CAI and CAII have bulky Tyr204 and Phe131 at isostructural positions [14]. Substituents in the ortho-position would be expected to interact with the narrower entrance to the active site closer to the $\mathrm{Zn}(\mathrm{II})$ and, therefore, would result in greater selectivity for CAIX and CAXII. We attempted to exploit these differences by designing inhibitors selective for CAIX and CAXII-ortho-substituted benzenesulfonamides. Two such compounds were designed to bear bulky groups in ortho- or para-positions to study the effect of substituent's position, size, and flexibility. The compounds were synthesized, and binding affinities and selectivities were determined for the entire set of 12 recombinant human CA isozymes. Key compounds were crystallized with several CA isozymes demonstrating their exact structural positions when bound to CAIX and other isozymes that lead to significant changes in affinity and selectivity for a particular isozyme. Several inhibitors possessed subnanomolar affinities for CAIX and greater than 100-fold selectivities over the remaining human CA isozymes. Thus, such compounds could be further developed for therapeutic purposes.

\section{Results and Discussion}

\subsection{Organic Synthesis of Designed Compounds}

Based on substituted halogenated benzenesulfonamide, a series of compounds were designed as potentially high-affinity and selective inhibitors of particular CA isozymes. Starting from methyl 2,4-dichloro-5-sulfamoyl-benzoate 1 and methyl 2,4-dibromo-5-sulfamoylbenzoate 2, the designed methyl halo 2- and 4-substituted-5-sulfamoyl-benzoates were synthesized (Scheme 1). Reaction conditions were first chosen according to our previous series where sulfur-containing nucleophiles reacted with dihalosulfamoylbenzamides [9]. The reactions of 2,4-dihalo-5-sulfamoyl-benzoates 1, 2 with thiols were performed in boiling methanol with triethylamine. However, the reaction was successful only with aromatic thiols (benzenethiol and naphthalene-1-thiol), yielding the para-substituted benzenesulfonamides $\mathbf{5}(\mathbf{a}, \mathbf{f})$ and $\mathbf{6 a}$. The reaction was very slow or absent, with thiols bearing aliphatic $\mathrm{CH}_{2}$ or $\mathrm{CH}$ group next to the sulfur atom.

To improve the synthesis and based on the reaction of dihalobenzamide with cyclohexanethiol [9], the polar protic solvent $\mathrm{MeOH}$ was replaced with a polar aprotic solvent DMSO. This replacement enabled the synthesis of ortho-substituted benzenesulfonamides (3b-e), $\mathbf{4 b}$ as the main product. However, by-products also formed, including para-substituted or even-disubstituted benzenesulfonamides.

The regioselectivity of the nucleophilic aromatic substitution of a halogen in methyl 2,4-dihalo-5-sulfamoyl-benzoates 1, 2 was investigated. All reactions were repeatedly performed in DMSO with triethylamine at $60{ }^{\circ} \mathrm{C}$ temperature for $72 \mathrm{~h}$. Determination of conversion yield, product ratio, and structure identification has been performed by NMR and HPLC/UV/MS (Table 1, and Supplementary material). 


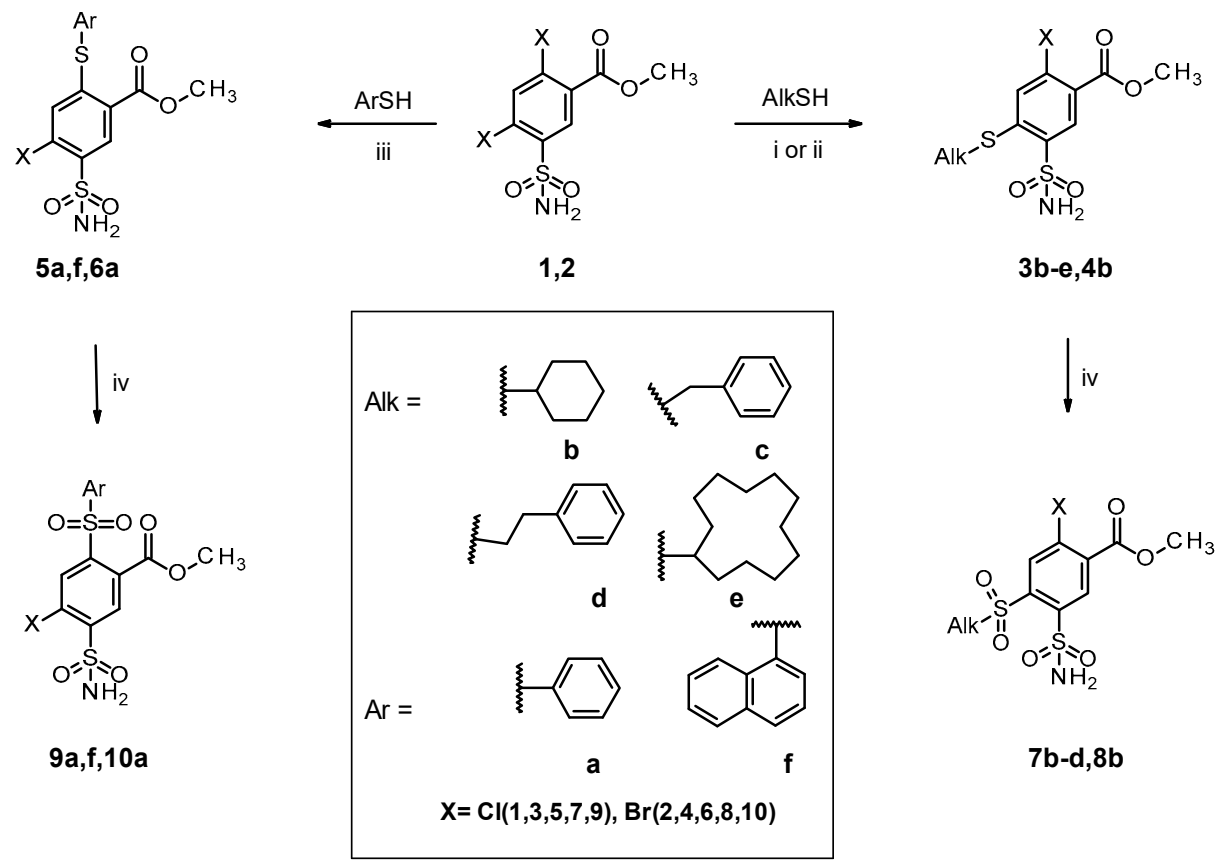

Scheme 1. The synthesis of methyl halo 2- and 4-substituted-5-sulfamoyl-benzoates: (i) TEA, DMSO, $60{ }^{\circ} \mathrm{C}$; (ii) $\mathrm{K}_{2} \mathrm{CO}_{3}, \mathrm{DMSO}, 60{ }^{\circ} \mathrm{C}$; (iii) TEA, $\mathrm{MeOH}, \Delta$; (iv) $\mathrm{H}_{2} \mathrm{O}_{2}, \mathrm{AcOH}, 75^{\circ} \mathrm{C}$. The legend in the middle explains the structures of alkyl $(\mathrm{Ak} ; \mathbf{b}, \mathbf{c}, \mathbf{d}, \mathbf{e})$ and aromatic (Ar; $\mathbf{a}, \mathbf{f})$ substituents and halogen atoms (Cl—compounds $1,3,5,7,9$ or $\mathrm{Br}-2,4,6,8,10)$.

Table 1. The reaction of 2,4-dihalo-5-sulfamoyl-benzoates 1, 2 with thiols and the ratios of the products as determined by NMR spectroscopy and HPLC/UV/MS system data (italic). * The separation of the 2- and 4-substituted isomers formed in the reaction of compounds $\mathbf{1}$ and $\mathbf{2}$ with phenylthiol using HPLC was unsuccessful.

\begin{tabular}{cccccc}
\hline $\begin{array}{c}\text { Starting } \\
\text { Compound }\end{array}$ & Conversion (\%) & 2-Substituted (\%) & 4-Substituted (\%) & $\begin{array}{c}\text { 2,4-Disubstituted } \\
\text { (\%) }\end{array}$ \\
\hline & $\begin{array}{l}30.07 \\
28.77\end{array}$ & $\begin{array}{c}18.70 \\
17.38\end{array}$ & $\begin{array}{c}81.30 \\
82.62\end{array}$ & $\begin{array}{c}90.91 \\
85.89\end{array}$ \\
\hline
\end{tabular}


Thiols could be arranged in descending order by their reactivity: phenyl $\geq$ naphthyl $>$ benzyl $\geq$ ethylphenyl $>$ cyclohexyl $\geq$ cyclododecyl. The formation of a disubstituted product was observed in the reaction with phenyl-, naphthyl-, and benzyl- thiols. The 2-substituted product was mainly formed in the reactions with aromatic thiols (naphthyland phenylthiol), while in the remaining cases, the formation of the 4-substituted product was dominant. In the case of bulky dodecylthiol, only the formation of the 4-substituted isomer was observed.

A group of 2-substituted methyl benzoates $\mathbf{5}(\mathbf{a}-\mathbf{d}, \mathbf{f})$ was synthesized via 2,4-dichloro5-sulfamoyl-benzamide (11) (Scheme 2) [9]. The nucleophilic substitution of chlorine occurred only in the para-position relative to the sulfonamide group. The amide group of the substituted products $\mathbf{1 2}(\mathbf{a}-\mathbf{d}, \mathbf{f})$ was converted to the ester group using thionyl chloride and $\mathrm{MeOH}$ to yield the 2 -substituted benzenesulfonamide methyl esters $\mathbf{5}(\mathbf{a}-\mathbf{d}, \mathbf{f})$. Oxidation of sulfanyl derivatives $\mathbf{3}(\mathrm{b}-\mathrm{d}), \mathbf{4 b}, \mathbf{5}(\mathbf{a}-\mathrm{d}, \mathrm{f}), \mathbf{6 a}$ to sulfonyl derivatives $\mathbf{7}(\mathrm{b}-\mathrm{d}), \mathbf{8 b}, \mathbf{9}(\mathbf{a}-\mathrm{d}, \mathbf{f})$, 10a (Schemes 1 and 2) was carried out using in situ generated peracetic acid.

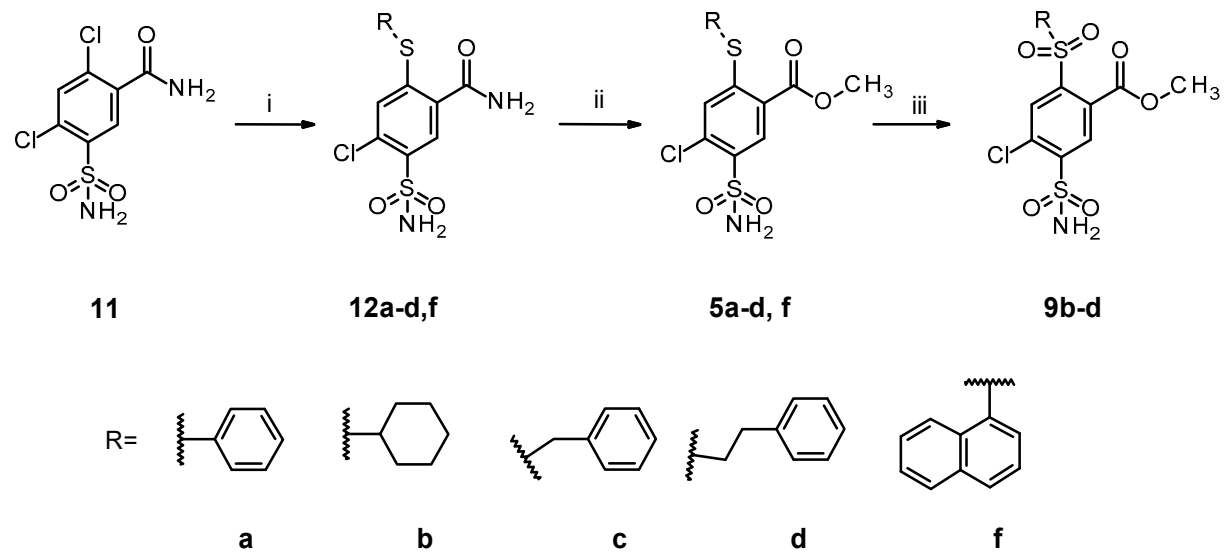

Scheme 2. Synthesis of 2-halo-4,5-disubstitutedbenzenesulfonamides: (i) TEA, DMSO, $60{ }^{\circ} \mathrm{C}$; (ii) $\mathrm{SOCl}_{2}, \mathrm{MeOH}, \Delta$; (iii) $\mathrm{H}_{2} \mathrm{O}_{2}, \mathrm{AcOH}, 75^{\circ} \mathrm{C}$.

\subsection{Thermodynamics of Compound Binding to CA Isozymes}

The chemical structures of 21 compounds used in this study are summarized in Figure 1A. The main goal was to determine the influence of the type and position of the sulfanyl or sulfonyl substituent on the affinity for human CA isozymes. The compounds were divided into four groups with different sulfanyl (-S-) or sulfonyl (-SO $\left.2_{2}^{-}\right)$substituents in para- or ortho-positions with respect to the sulfonamide group. All compounds had the same ester group in the meta-position. The influence of the diversity of the meta group on the binding affinity to CAs has been investigated and described in greater detail in a previous publication [9]. We found no significant difference in binding for compounds with chlorine or bromine atoms in that study. Therefore, there is only one analogous brominated compound for comparison $(4 \mathbf{b}, \mathbf{6 a}, \mathbf{8 b}, \mathbf{1 0 a})$ in each of the four groups.

Dissociation constants (Table 2) of every compound for each of the 12 catalytically active human CA isozymes were measured using the fluorescent thermal shift assay (FTSA). Some experimental data of selected compounds are provided in Figures S1 and S2 in the Supplementary material. The observed constants $\left(K_{d \_o b s}\right)$ were converted to the observed standard change in the Gibbs energy of binding $\left(\Delta G_{o b s}=R T \ln K_{d \_o b s}\right.$, where $R$ is the universal ideal gas constant and $T$ is the temperature), shown in Figure 1B, upper panel, and Table S1. For visual simplicity, the affinity is averaged for all compounds belonging to one of the four groups and shown in the Figure by coloring the groups: $\mathbf{3}(\mathbf{b}-\mathbf{e}), \mathbf{4 b}$ are blue rhombs, $\mathbf{5}(\mathbf{a}-\mathbf{d}, \mathbf{f}), \mathbf{6 a}$ are orange squares, $\mathbf{7}(\mathbf{b}-\mathbf{d}), \mathbf{8 b}$ are cyan triangles, and $\mathbf{9}(\mathbf{a}-\mathbf{d}, \mathbf{f}), \mathbf{1 0 a}$ are yellow circles (Figure 1B). The bars show the range from the strongest to the weakest affinity for each CA isozyme in that group of compounds (not the error bars). 
A<smiles>[R]Sc1cc([X])c(C(=O)OC)cc1S(N)(=O)=O</smiles><smiles>CC=[13C][13C][13C]</smiles><smiles>[X]c1cc(S([R])(=O)=O)c(S(N)(=O)=O)cc1C(=O)OC</smiles>

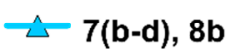<smiles>[R]Sc1cc([X])c(S(N)(=O)=O)cc1C(=O)OC</smiles>

$5(a-d, f), 6 a$<smiles>[X]c1cc(S([R])(=O)=O)c(C(=O)OC)cc1S(N)(=O)=O</smiles>

$9(a-d, f), 10 a$

$\mathrm{X}: \mathrm{Cl}(\mathbf{3}(\mathbf{b}-\mathrm{e}), \mathbf{5}(\mathbf{a}-\mathrm{d}, \mathrm{f}), 7(\mathbf{b}-\mathrm{d}), \mathbf{9}(\mathbf{a}-\mathrm{d}, \mathrm{f}), \mathrm{Br}(\mathbf{4 b}, \mathbf{6 a}, \mathbf{8 b}, \mathbf{1 0 a})$

$\mathrm{R}$ :

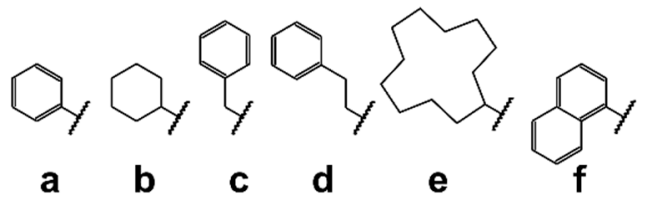

B Carbonic anhydrase isoenzyme I II III IV VA VB VI VII IX XII XIII XIV
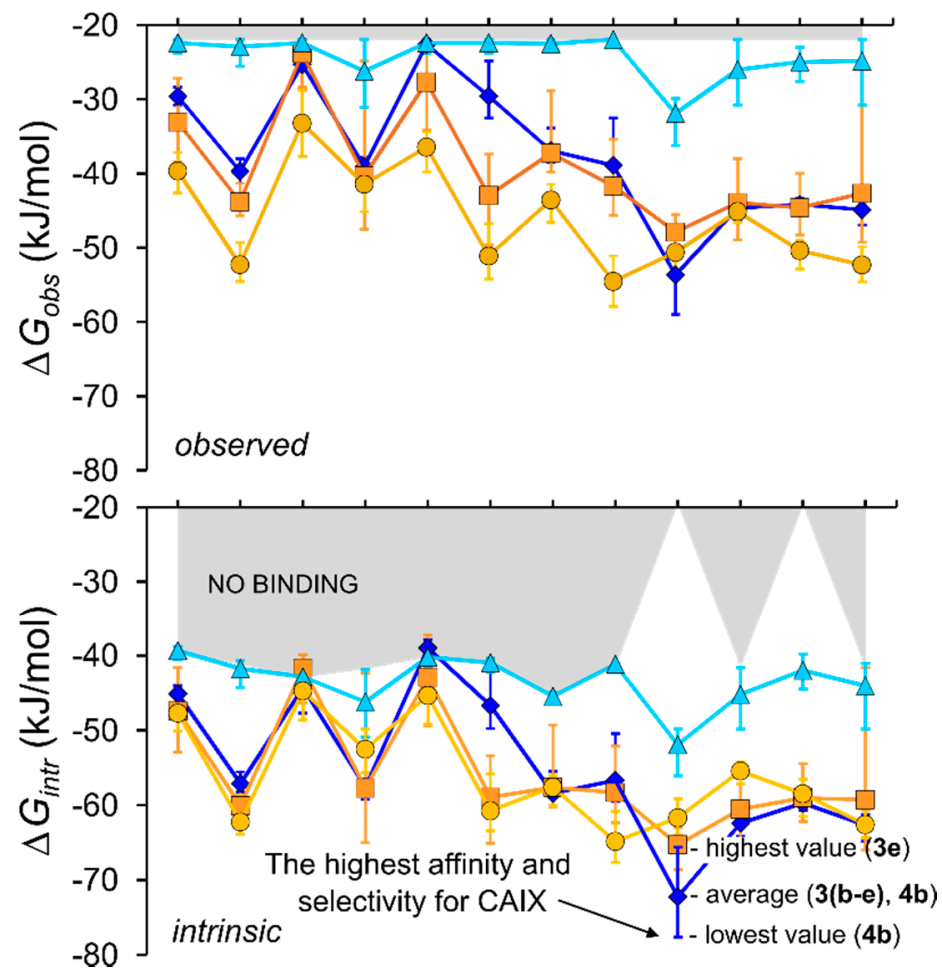

Figure 1. (A) Chemical structures of the four groups of compounds-methyl halo 2- or 4-substituted5-sulfamoyl-benzoates containing chlorine or bromine and substituents listed at the bottom of the panel. (B) Averaged change in the standard observed (upper panel) or intrinsic (lower panel) Gibbs energy for compounds belonging to one of the four groups: $\mathbf{3}(\mathbf{b}-\mathbf{e}), \mathbf{4 b}-\mathrm{blue}$ rhombs, $\mathbf{5}(\mathbf{a}-\mathbf{d}, \mathbf{f}), \mathbf{6 a}-$ orange squares, $\mathbf{7}(\mathbf{b}-\mathbf{d}), \mathbf{8 b}-$ cyan triangles, and $\mathbf{9}(\mathbf{a}-\mathbf{d}, \mathbf{f}), \mathbf{1 0} \mathbf{a}-$ yellow circles. The bars show the margin between the strongest and weakest affinity of compounds in that group for the indicated CA isozyme. The intrinsic binding affinity of compounds $\mathbf{3}(\mathbf{b}-\mathbf{e}), \mathbf{4} \mathbf{b}$ to CAIX is highlighted: the blue rhombus is the average of all five interactions, the bar above shows the weakest CAIX interaction with $3 \mathbf{e}$, and below is the strongest with $\mathbf{4 b}$. Compounds in this group have the highest selectivity and affinity for CAIX.

Interaction of CA with any primary sulfonamide is $\mathrm{pH}$-dependent in identical shape. The affinity is greatest in the near-neutral range and decreases by exactly 10-fold with every $\mathrm{pH}$ unit in the acidic and alkaline $\mathrm{pH}$ regions. This is explained by the binding mechanism where the deprotonated sulfonamide compound replaces a water molecule (but not a hydroxide ion) coordinated by the $\mathrm{Zn}$ (II) in the active site of CA. The deprotonated state of the sulfonamide amino group bound to CA is directly observed by the neutron diffraction structures [15]. However, the sulfonamide state in the solution is predominantly in the protonated form because sulfonamide $\mathrm{p} K_{\mathrm{a}}$ is usually in the region of 9-10. Both the compound and the protein have to undergo protonation-deprotonation reactions to be able to bind. These binding-linked reactions significantly reduce the affinity. Interaction energies of the binding-able states of the protein and ligand are termed intrinsic. However, since the protonation reactions occur indistinguishably from protein-ligand binding, we experimentally observe diminished energies, termed observed. 
Table 2. Intrinsic $\left(K_{d \_i n t r}\right)$, calculated according to the model, and observed ( $K_{d \_o b s}$ at $\left.\mathrm{pH}=7.0\right)$, determined by the fluorescent thermal shift assay, dissociation constants, $K_{d}(\mathrm{nM})$, of investigated compounds binding to all catalytically active human carbonic anhydrases (CAs) at $37^{\circ} \mathrm{C}$. $\mathrm{p} K_{a}$ values of the sulfonamide group were calculated from spectra at various $\mathrm{pH}$ as described in Methods and are listed to all compounds. Some compounds exhibited poorer solubility, which was observed visually and prompted in absorption spectra. Therefore, for such compounds, the $\mathrm{p} K_{a}$ value was assigned based on the average value of the other compounds in that group and is marked with *.

\begin{tabular}{|c|c|c|c|c|c|c|c|c|c|c|c|c|c|c|c|c|c|}
\hline $\begin{array}{c}\text { Compound } \\
\text { (Lab. Name) }\end{array}$ & Chemical Structure & $\begin{array}{l}\text { ortho } \\
\text { Substituent }\end{array}$ & $\begin{array}{c}\text { para } \\
\text { Substituent }\end{array}$ & $\mathrm{p} K_{a}$ & $K_{d}(\mathrm{nM})$ & CAI & CAII & CAIII & CAIV & CAVA & CAVB & CAVI & CAVII & CAIX & CAXII & CAXIII & CAXIV \\
\hline 1 & & \multirow{2}{*}{$\mathrm{Cl}$} & \multirow{2}{*}{$\mathrm{Cl}$} & \multirow{2}{*}{8.9} & Observed & 14,000 & 71 & 50,000 & 180 & 6700 & 310 & 170 & 67 & 59 & 560 & 83 & 72 \\
\hline$(E A 2-1)$ & & & & & Intrinsic & 160 & 0.39 & 150 & 0.65 & 55 & 1.9 & 0.19 & 0.32 & 0.21 & 2.7 & 0.94 & 0.35 \\
\hline 2 & & \multirow{2}{*}{$\mathrm{Br}$} & \multirow{2}{*}{$\mathrm{Br}$} & \multirow{2}{*}{8.8} & Observed & 20,000 & 91 & $\geq 2 \times 10^{5}$ & 140 & 3700 & 33 & 290 & 56 & 120 & 330 & 63 & 40 \\
\hline (LJ14-4) & & & & & Intrinsic & 290 & 0.63 & $\geq 750$ & 0.63 & 38 & 0.26 & 0.41 & 0.34 & 0.52 & 2 & 0.89 & 0.24 \\
\hline $3 b$ & & \multirow{2}{*}{ cyclohexyl } & \multirow{2}{*}{$\mathrm{Cl}$} & \multirow{2}{*}{9.6} & Observed & 17,000 & 250 & 40,000 & 400 & 100,000 & 11,000 & 330 & 150 & 0.33 & 33 & 50 & 13 \\
\hline$(E A 2-3)$ & & & & & Intrinsic & 39 & 0.28 & 24 & 0.29 & 170 & 14 & 0.080 & 0.15 & 0.00020 & 0.030 & 0.11 & 0.010 \\
\hline$(E A 2-4)$ & & benzyl & $\mathrm{Cl}$ & 9.5 & Intrinsic & 20 & 0.16 & 61 & 0.11 & $\geq 420$ & 7.9 & 0.10 & 0.19 & 0.0030 & 0.030 & 0.11 & 0.050 \\
\hline $3 \mathrm{~d}$ & & \multirow{2}{*}{ 2-phenylethyl } & \multirow{2}{*}{$\mathrm{Cl}$} & \multirow{2}{*}{9.6} & Observed & 13,000 & 170 & 15,000 & 430 & 110,000 & 10,000 & 630 & 100 & 13 & 53 & 38 & 43 \\
\hline (EA2-5) & & & & & Intrinsic & 30 & 0.18 & 9.3 & 0.30 & 190 & 13 & 0.14 & 0.10 & 0.0090 & 0.050 & 0.090 & 0.040 \\
\hline $3 \mathrm{e}$ & & \multirow{2}{*}{ cyclododecyl } & \multirow{2}{*}{$\mathrm{Cl}$} & & Observed & 12,000 & 400 & $\geq 2 \times 10^{5}$ & 200 & $\geq 2 \times 10^{5}$ & 67,000 & 2000 & 3300 & 0.44 & 41 & 27 & 37 \\
\hline (EA2-12) & & & & & Intrinsic & 27 & 0.44 & $\geq 120$ & 0.14 & $\geq 330$ & 84 & 0.46 & 3.2 & 0.00030 & 0.040 & 0.060 & 0.040 \\
\hline $4 \mathrm{~b}$ & & \multirow{2}{*}{ cyclohexyl } & \multirow{2}{*}{$\mathrm{Br}$} & \multirow{2}{*}{$9.6^{*}$} & Observed & 6700 & 200 & 48,000 & 330 & $\geq 2 \times 10^{5}$ & 3300 & 560 & 220 & 0.12 & 16 & 33 & 20 \\
\hline (LJ15-12) & & & & & Intrinsic & 15 & 0.22 & 29 & 0.24 & $\geq 330$ & 4.2 & 0.13 & 0.22 & 0.000080 & 0.020 & 0.080 & 0.020 \\
\hline$(E A 2-2)$ & & $\mathrm{Cl}$ & phenyl & 9.4 * $\mathrm{LS}$ & Intrinsic & 12 & 0.060 & 16 & 0.020 & $\geq 530$ & 0.50 & 0.070 & 0.080 & 0.0030 & 0.0090 & 0.070 & 0.030 \\
\hline $5 b$ & & \multirow{2}{*}{$\mathrm{Cl}$} & \multirow{2}{*}{ cyclohexyl } & \multirow{2}{*}{9.4} & Observed & 330 & 20 & $\geq 2 \times 10^{5}$ & 67 & 4000 & 5.7 & 210 & 21 & 7.5 & 13 & 10 & 5.1 \\
\hline (EA1-3N) & & & & & Intrinsic & 1.2 & 0.040 & $\geq 190$ & 0.080 & 11 & 0.010 & 0.070 & 0.030 & 0.0080 & 0.020 & 0.040 & 0.0080 \\
\hline $5 \mathrm{c}$ & & \multirow{2}{*}{$\mathrm{Cl}$} & heprow & & Observed & 2000 & 33 & $\geq 2 \times 10^{5}$ & 120 & 1800 & 470 & 290 & 130 & 14 & 400 & 100 & 47 \\
\hline$(E A 1-4 N)$ & & & 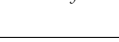 & 我 & $\begin{array}{l}\text { Intrinsic } \\
\end{array}$ & 7.3 & 0.060 & $\geq 190$ & 0.13 & 4.8 & 0.92 & 0.10 & 0.19 & 0.020 & 0.61 & 0.36 & 0.070 \\
\hline $5 \mathrm{~d}$ & & & 2-phenulethul & & Observed & 3400 & 27 & 89,000 & 1000 & 3800 & 4.4 & 850 & 24 & 12 & 180 & 7.4 & 17 \\
\hline (EA1-5N) & & . & & - & Intrinsic & 16 & 0.060 & 110 & 1.5 & 13 & 0.010 & 0.38 & 0.050 & 0.020 & 0.34 & 0.030 & 0.030 \\
\hline $5 \mathrm{f}$ & & & 1-naphthy & & Observed & 27,000 & 110 & $\geq 2 \times 10^{5}$ & 66,000 & 96,000 & 510 & 14,000 & 1100 & 22 & 66 & 57 & 63,000 \\
\hline (EA2-NF) & & - & & 我 & Intrinsic & 98 & 0.20 & $\geq 190$ & 75 & 250 & 1.0 & 5.0 & 1.7 & 0.020 & 0.10 & 0.21 & 97 \\
\hline $6 a$ & & & phenul & & Observed & 2500 & 80 & $\geq 2 \times 10^{5}$ & 40 & 86,000 & 31 & 420 & 210 & 9.8 & 20 & 16 & 13 \\
\hline (LI15-11) & & to & (2) & the & Intrinsic & 9.2 & 0.14 & $\geq 190$ & 0.050 & 230 & 0.060 & 0.15 & 0.32 & 0.010 & 0.030 & 0.060 & 0.020 \\
\hline
\end{tabular}


Table 2. Cont.

\begin{tabular}{|c|c|c|c|c|c|c|c|c|c|c|c|c|c|c|c|c|c|}
\hline $\begin{array}{c}\text { Compound } \\
\text { (Lab. Name) }\end{array}$ & Chemical Structure & $\begin{array}{c}\text { ortho } \\
\text { Substituent }\end{array}$ & $\begin{array}{c}\text { para } \\
\text { Substituent }\end{array}$ & $\mathrm{p} K_{a}$ & $K_{d}(\mathrm{nM})$ & CAI & CAII & CAIII & CAIV & CAVA & CAVB & CAVI & CAVII & C A IX & CAXII & CAXIII & CAXIV \\
\hline $7 \mathrm{~b}$ & & \multirow{2}{*}{ cyclohexyl } & \multirow{2}{*}{$\mathrm{Cl}$} & \multirow{2}{*}{9.8} & Observed & 100,000 & 50,000 & 100,000 & 41,000 & 100,000 & 100,000 & 190,000 & $\geq 2 \times 10^{5}$ & 9200 & 67,000 & 69,000 & 69,000 \\
\hline (EA2-30) & & & & & Intrinsic & 150 & 35 & 38 & 19 & 110 & 79 & 28 & $\geq 120$ & 4.2 & 41 & 99 & 42 \\
\hline $7 \mathrm{c}$ & & \multirow{2}{*}{ benzyl } & \multirow{2}{*}{$\mathrm{Cl}$} & \multirow{2}{*}{$9.8^{*} \mathrm{LS}$} & Observed & $\geq 2 \times 10^{5}$ & 190,000 & $\geq 2 \times 10^{5}$ & 5900 & $\geq 2 \times 10^{5}$ & $\geq 2 \times 10^{5}$ & 130,000 & $\geq 2 \times 10^{5}$ & 790 & 6700 & 140,000 & 6700 \\
\hline (EA2-40) & & & & & Intrinsic & $\geq 290$ & 130 & $\geq 76$ & 2.7 & $\geq 210$ & $\geq 160$ & 19 & $\geq 120$ & 0.36 & 4.1 & 200 & 4.1 \\
\hline $7 \mathrm{~d}$ & & 2-phenylethyl & $\mathrm{Cl}$ & $9.8 * \mathrm{LS}$ & Observed & $\geq 2 \times 10^{5}$ & $\geq 2 \times 10^{5}$ & $\geq 2 \times 10^{5}$ & $\geq 2 \times 10^{5}$ & $\geq 2 \times 10^{5}$ & $\geq 2 \times 10^{5}$ & 130,000 & $\geq 2 \times 10^{5}$ & 6700 & 34,000 & 22,000 & $\geq 2 \times 10^{5}$ \\
\hline $8 b$ & & \multirow{2}{*}{ cyclohexyl } & \multirow{2}{*}{$\mathrm{Br}$} & \multirow{2}{*}{9.9} & Observed & $\geq 2 \times 10^{5}$ & $\geq 2 \times 10^{5}$ & $\geq 2 \times 10^{5}$ & $\geq 2 \times 10^{5}$ & $\geq 2 \times 10^{5}$ & $\geq 2 \times 10^{5}$ & $\geq 2 \times 10^{5}$ & $\geq 2 \times 10^{5}$ & 6700 & $\geq 2 \times 10^{5}$ & 71,000 & $\geq 2 \times 10^{5}$ \\
\hline (LJ15-12o) & & & & & Intrinsic & $\geq 230$ & $\geq 110$ & $\geq 60$ & $\geq 16$ & $\geq 170$ & $\geq 130$ & $\geq 23$ & $\geq 97$ & 2.4 & $\geq 97$ & 82 & $\geq 97$ \\
\hline $9 a$ & & \multirow{2}{*}{$\mathrm{Cl}$} & \multirow{2}{*}{ phenyl } & \multirow{2}{*}{8.2} & Observed & 140 & 0.91 & 3300 & 25 & 770 & 13 & 56 & 0.45 & 3.3 & 22 & 5.6 & 0.83 \\
\hline (EA2-2o) & & & & & Intrinsic & 7.9 & 0.020 & 48 & 0.42 & 30 & 0.40 & 0.30 & 0.010 & 0.060 & 0.51 & 0.30 & 0.020 \\
\hline $9 b$ & & \multirow{2}{*}{$\mathrm{Cl}$} & \multirow{2}{*}{ cyclohexyl } & \multirow{2}{*}{8.2} & Observed & 67 & 0.67 & 2800 & 200 & 500 & 0.75 & 42 & 0.18 & 1 & 14 & 2.7 & 0.64 \\
\hline (EA1-3No) & & & & & Intrinsic & 3.7 & 0.020 & 40 & 3.4 & 20 & 0.020 & 0.22 & 0.0040 & 0.020 & 0.33 & 0.15 & 0.010 \\
\hline 9c & & $\mathrm{Cl}$ & benzyl & 8.2 & Observed & 560 & 5 & 450 & 100 & 830 & 1.1 & 14 & 2.5 & 2.5 & 20 & 5 & 2.6 \\
\hline 9d & & \multirow{2}{*}{$\mathrm{Cl}$} & \multirow{2}{*}{ 2-phenylethyl } & \multirow{2}{*}{8.4} & Observed & 330 & 1.7 & 920 & 140 & 200 & 1.1 & 26 & 0.85 & 2.5 & 48 & 3 & 1.3 \\
\hline (EA1-5No) & & & & & Intrinsic & 12 & 0.030 & 8.5 & 1.6 & 5.1 & 0.020 & 0.090 & 0.010 & 0.030 & 0.72 & 0.10 & 0.020 \\
\hline 9f & & \multirow{2}{*}{$\mathrm{Cl}$} & \multirow{2}{*}{ 1-naphthyl } & \multirow{2}{*}{8.4} & Observed & 140 & 1.3 & 14,000 & 50 & 1400 & 3.4 & 100 & 0.67 & 10 & 50 & 1.3 & 4 \\
\hline (EA2-Nfo) & & & & & Intrinsic & 5.1 & 0.020 & 130 & 0.55 & 36 & 0.060 & 0.35 & 0.010 & 0.11 & 0.74 & 0.040 & 0.060 \\
\hline 10a & & \multirow{2}{*}{$\mathrm{Br}$} & \multirow{2}{*}{ phenyl } & & Observed & 330 & 2.3 & 4800 & 370 & 1600 & 5.3 & 110 & 0.67 & 3.3 & 16 & 4.3 & 2 \\
\hline (LJ15-110) & & & & 8.4 & Intrinsic & 12 & 0.040 & 44 & 4.0 & 41 & 0.10 & 0.37 & 0.010 & 0.040 & 0.24 & 0.15 & 0.030 \\
\hline Acetazolamide & & & & & Observed & 2400 & 46 & 40,000 & 87 & 840 & 140 & 220 & 13 & 21 & 130 & 120 & 63 \\
\hline & & & & 1.0 & Intrinsic & 1100 & 9.8 & 4600 & 12 & 270 & 34 & 9.8 & 2.4 & 2.9 & 24 & 53 & 12 \\
\hline
\end{tabular}

Not determined, ND; low solubility, LS. ${ }^{*} \mathrm{p} K_{a}$ value was assigned based on the average value of the other compounds in that group. The measurement limit is $\geq 2 \times 10^{5}$. The highest used ligand concentration was $200 \mu \mathrm{M}$. Intrinsic values are calculated according to the model described in the Methods section. 
The intrinsic dissociation constants were calculated according to the model described in the Methods section and Supplementary material using measured $\mathrm{p} K_{a}$ values of the sulfonamide group of the compounds (Table 2). It is more appropriate to use the intrinsic parameters in interpreting the interactions, as they help separate the linked protonation reactions that can lead to erroneous conclusions [16]. The intrinsic standard change in the Gibbs energy of binding is shown in Figure 1B, lower panel, and Table S2. These parameters were also used in the analysis of crystal structures.

\subsection{X-ray Crystal Structures and Correlations with Compound Binding Thermodynamics to CA Isozymes}

Eight crystal structures of CA complexes with compounds are presented in this study: 9a bound to CAI and CAII, $3 \mathbf{b}, \mathbf{3 d}, \mathbf{5 b}$, and $\mathbf{9 a}$ bound to CAXII, $3 \mathbf{b}$ bound to CAIX and mimic-CAIX (mutant of CAII containing amino acids in the active site as in CAIX: A65S, N67Q, I91L, F130V, V134L, and L203A). The electron density maps of the ligands bound in the active site of CA are shown in Figure S3. The data collection and refinement statistics are presented in Table S3. The crystal structures of CAI, CAII (and mimic-CAIX), CAIX, and CAXII complexes in the asymmetric unit contained 2, 1, 4, and 4 protein subunits, respectively.

The structure-thermodynamics correlations that determine the recognition between the CA active site and the ligand will be analyzed in three sections:

(i) methyl 2-halo-4-substituted-5-sulfamoyl-benzoates, abbreviated ortho- by substituent at the ortho- position relative to sulfonamide group;

(ii) methyl 4-halo-2-substituted-5-sulfamoyl-benzoates, abbreviated as para-,

(iii) the position of the substituent in benzenesulfonamide is compared in these two groups of compounds.

\subsubsection{Methyl 2-Halo-4-Substituted-5-Sulfamoyl-Benzoates Binding to CA Isozymes}

In the group of ortho- sulfanyl-3(b-e), $4 \mathbf{b}$, and sulfonyl- $7(\mathbf{b}-\mathbf{d}), \mathbf{8 b}$ substituted benzenesulfonamides, the chlorinated $3 b$, and brominated $4 \mathbf{b}$ bound similarly. Their $K_{d}$ differed by less than 3-fold; not a significant difference within the error limits (Table 2). Compounds 7 bound most isozymes with barely detectable affinity, except CAIX, where chlorinated and brominated bound similarly $\left(K_{d \_o b s}(7 \mathbf{b})=9200 \mathrm{nM}\right.$ and $\left.K_{d \_o b s}(8 \mathbf{b})=6700 \mathrm{nM}\right)$. Sulfonyl $\left(-\mathrm{SO}_{2^{-}}, \mathbf{7}(\mathbf{b}-\mathbf{d}), \mathbf{8 b}\right)$ compounds bound CA significantly weaker than the parent compound $\mathbf{1}$ or analogous sulfanyl compounds $\mathbf{3 b} \mathbf{b}-\mathbf{e}$. The strongest interaction with CAIX was likely due to its wider active site than in other CAs [10]. The sulfonyl compounds likely were in an unfavorable conformation for binding and prevented an optimal formation of the sulfonamide group-nitrogen and protein- $\mathrm{Zn}$ (II) coordination bond due to steric hindrance.

The $\mathrm{p} K_{a}$ values of the sulfonamide amino group of a series of these compounds were determined. Although the compounds showed limited solubility, the absorption spectra of $\mathbf{7 b}$ and $\mathbf{8 b}$ at different $\mathrm{pH}$ were used to determine their $\mathrm{p} K_{a}$ values, 9.8 and 9.9, respectively (Supplementary material, Figure S5). The same, 9.8, value was assigned to other compounds (7c and $7 \mathbf{d})$ in the same group. Para-substituted sulfonyl $\left(-\mathrm{SO}_{2}^{-}\right)$compounds $\mathbf{9}(\mathbf{a}-\mathbf{d}, \mathbf{f})$, and 10a $\left(\mathrm{p} K_{a}=8.2-8.4\right)$ had lower $\mathrm{p} K_{a}$ values than sulfanyl (-S-) compounds 5(a-d,f), and $\mathbf{6 a}$ $\left(\mathrm{p} K_{a}=9.3-9.4\right)$, while ortho-substituted compounds showed the opposite (Figure 1B, upper panel and Table 2). The $\mathrm{p} K_{a}$ values were 9.9 for sulfonyl $\left(-\mathrm{SO}_{2^{-}}\right)$compounds $\mathbf{7}(\mathbf{b}-\mathbf{d}, \mathbf{f}), \mathbf{8 b}$, and 9.5-9.6 for sulfanyl (-S-) compounds $\mathbf{3}(\mathbf{b}-\mathbf{e}), \mathbf{4 b}$. Therefore, oxidation did not reduce the $\mathrm{p} K_{a}$ of the sulfonamide group in all cases. The $\mathrm{p} K_{a}$ values were well correlated with chemical shifts determined by NMR (Supplementary material, Figure S6). Chemical shifts show the same trend: values of ortho-sulfonyl compounds were lower than sulfanyl, and, in contrast, para-sulfonyl compounds had higher values than sulfanyl.

Sulfanyl-compounds $\mathbf{3 b}-\mathbf{e}$ and $\mathbf{4 b}$ bound weakly to CAI, CAIII (narrow entrance to the active site due to Phe198), CAVA, and CAVB. However, compounds had $\mu \mathrm{M}$ affinity to CAII, CAIV, CAVI, CAVII and even approximately 10 -fold stronger $\left(K_{d \_o b s}\right.$ is $\left.13-53 \mu \mathrm{M}\right)$ to CAXII, CAXIII, and CAXIV (the measured affinity to CAIX is up to $0.12 \mu \mathrm{M}$ (Table 2 and Figure $1 \mathrm{~B}$ ). 
Comparison between parent compound $\mathbf{1}$ and the ortho-substituted sulfanyl compounds showed that the hydrophobic substituent had a significant effect (Figure 2). The intrinsic affinity for CAXII $(-11.4 \mathrm{~kJ} / \mathrm{mol})$, CAXIII $(-5.4 \mathrm{~kJ} / \mathrm{mol})$, CAXIV $(-8.6 \mathrm{~kJ} / \mathrm{mol})$, and especially for CAIX ( $-17.5 \mathrm{~kJ} / \mathrm{mol}$ or about 1000 -fold) significantly increased, and CAVA $(2.9 \mathrm{~kJ} / \mathrm{mol})$ and CAVB $(5.1 \mathrm{~kJ} / \mathrm{mol})$ decreased $(\mathbf{1} \rightarrow \mathbf{3 b})$. The affinity strongly depended on the flexibility of the substituent and shorter substituents in compounds $\mathbf{3 b}$ and $\mathbf{3 e}$ had higher affinity to CAIX than longer and more flexible substituents in compounds $3 \mathrm{c}$ and 3d: the difference was at least about $6 \mathrm{~kJ} / \mathrm{mol}$ or about 10 -fold $\left(\Delta G_{\text {intr }}(3 \mathbf{b})=-75.0 \mathrm{~kJ} / \mathrm{mol}\right.$, $\left.\Delta G_{\text {intr }}(3 \mathbf{c})=-68.8 \mathrm{~kJ} / \mathrm{mol}, \Delta G_{\text {intr }}(3 \mathbf{d})=-65.6 \mathrm{~kJ} / \mathrm{mol}, \Delta G_{\text {intr }}(3 \mathbf{e})=-74.2 \mathrm{~kJ} / \mathrm{mol}\right)$. The affinity for CAVII decreased significantly $(9.0 \mathrm{~kJ} / \mathrm{mol})$ from compound $3 \mathbf{d}$ to compound $3 \mathbf{e}$, possibly due to the size of the substituent. In other cases, the differences were within the error margin.

We compared the crystal structures of several compounds in two different CA isozymes (Figure 2B-D). Figure 2B shows the binding mode of $\mathbf{3 b}$ and $\mathbf{3 d}$ in the active site of CAXII. These compounds are structurally similar and differ only in the size of large hydrophobic ortho substituents; compound $\mathbf{3 b}$ has the octyl, while $\mathbf{3 d}$ has the 2-phenylethyl moiety. The binding modes of both ligands in the active site of CAXII were the same: ortho groups were directed to the hydrophobic part of the active site, while meta substituents were orientated to the hydrophilic part. The binding affinities and enthalpy changes to CAXII were almost identical $\left(\Delta G_{\text {intr }}=-62.3 \mathrm{~kJ} / \mathrm{mol}, \Delta H_{\text {intr }}=-48.0 \mathrm{~kJ} / \mathrm{mol}(3 \mathbf{b})\right.$ vs. $\Delta G_{\text {intr }}=-61.1 \mathrm{~kJ} / \mathrm{mol}$, $\Delta H_{\text {intr }}=-50.1 \mathrm{~kJ} / \mathrm{mol}(\mathbf{3 d})$, Figure 2B). Experimental data of the $\Delta H_{o b s}$ are shown in the Supplementary material in Figure $\mathrm{S} 8$.

Figure 2C shows the superposition of $\mathbf{3 b}$ in the active sites of CAIX and CAXII. The positions of the compounds were similar. However, the binding affinities of $\mathbf{3 b}$ to CAIX and CAXII differed significantly and were 150 times stronger to CAIX than CAXII $\left(K_{d \_i n t r}=0.030 \mathrm{nM}\right.$ or $\Delta G_{i n t r}=-62.3 \mathrm{~kJ} / \mathrm{mol}$ to CAXII and $K_{d \_i n t r} 0.20 \mathrm{pM}$ or $\Delta G_{\text {intr }}=$ $-75.0 \mathrm{~kJ} / \mathrm{mol}$ to CAIX, Table 2 and Table S2). Again, the side chains interacting with $\mathbf{3 b}$ in CAIX and CAXII were different. They were more hydrophobic in CAIX (A203, L135, V131, L91, and Q67) and more hydrophilic in CAXII (N204, S135, V131, T91, and K68). Thus, these differences could be related to the solvation entropy because binding to CAIX was much more entropy-driven than to CAXII $\left(\Delta H_{\text {intr }}=-29.9 \mathrm{~kJ} / \mathrm{mol},-T \Delta S_{\text {intr }}=-45.1\right.$ $\mathrm{kJ} / \mathrm{mol}$ to CAIX and $\Delta H_{\text {intr }}=-48.0 \mathrm{~kJ} / \mathrm{mol},-T \Delta S_{\text {intr }}=-14.3 \mathrm{~kJ} / \mathrm{mol}$ to CAXII).

The binding of $\mathbf{3 b}$ to CAIX and mimic-CAIX is compared in Figure 2D. Mimic-CAIX is CAII with multiple point mutations that replace the side chains of the active site of CAII with the corresponding residues of CAIX. It has been shown that six-point mutations (A65S, N67Q, I91L, F130V, V134L, and L203A) are sufficient to switch the binding mode of the selective ligand [17-19] (mutations slightly different A65S, N67Q, E69T, I91L, F131V, K170E, and L204A). The ligand positions were similar except for the shift of the ortho cyclooctyl group. Nevertheless, the native CAIX bound $3 \mathbf{b} 10$-fold more strongly than the mimicCAIX (Supplementary material Figure S1). The crystal structure could not answer this question with certainty, but the differences in binding affinities between CAIX and CAII were even greater: $\Delta G_{\text {intr }}=-56.7 \mathrm{~kJ} / \mathrm{mol}$ to CAII, $\Delta G_{\text {intr }}=-67.4 \mathrm{~kJ} / \mathrm{mol}$ to mimic-CAIX and $\Delta G_{\text {intr }}=-75.0 \mathrm{~kJ} / \mathrm{mol}$ to CAIX. The mutations introduced in CAII mimicked the active site of CAIX. The binding affinities were more similar to CAIX than CAII, and very similar enthalpy changes between CAIX and mimic-CAIX were observed: $\Delta H_{\text {intr }}=-29.9 \mathrm{~kJ} / \mathrm{mol}$ to CAIX and $\Delta H_{\text {intr }}=-31.2 \mathrm{~kJ} / \mathrm{mol}$ to mimic-CAIX). 


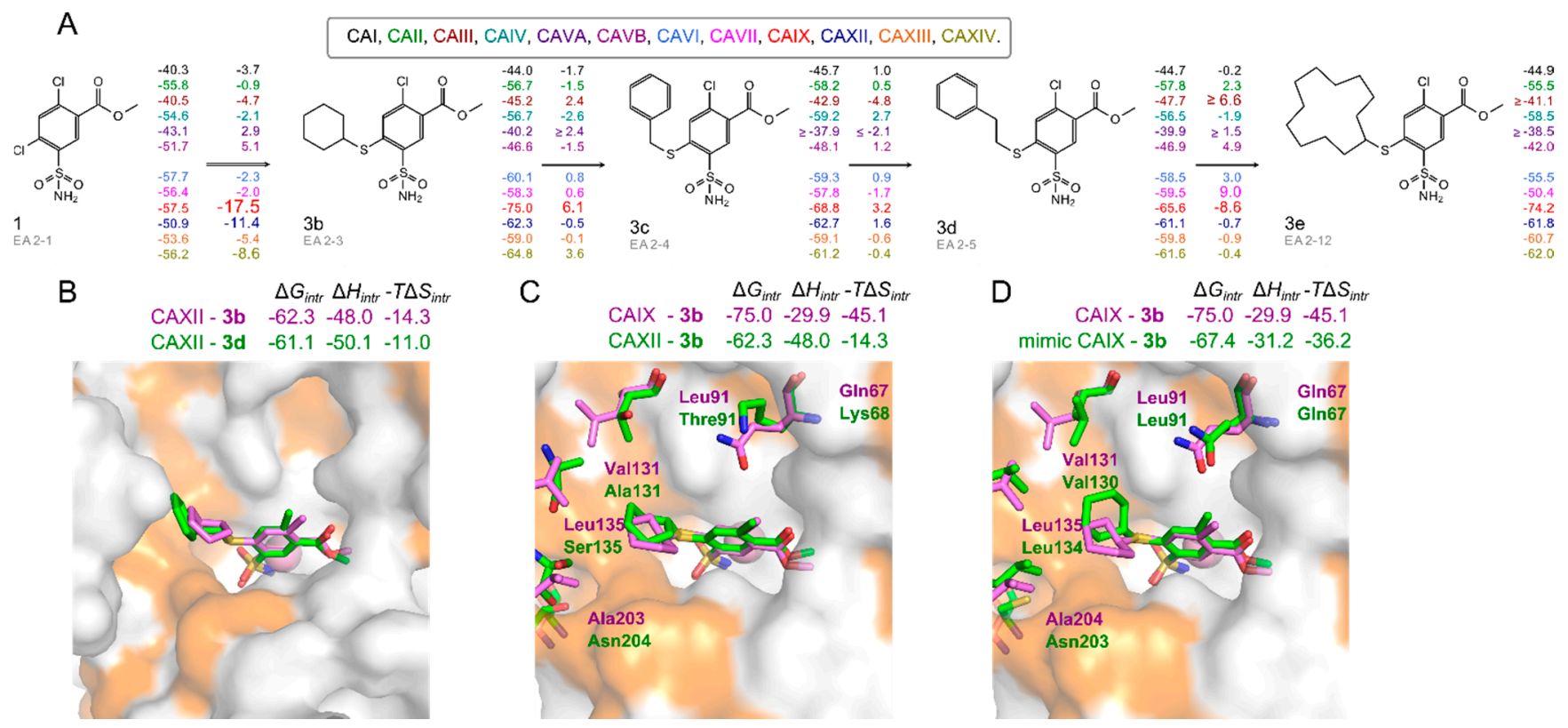

Figure 2. Correlation of compound chemical structures with the changes in standard intrinsic Gibbs energy upon binding and the comparison of the crystal structures between CA isozymes. (A) Differences of $\Delta G_{\text {intr }}$ between neighboring compounds are listed on the connecting arrows. All values have units of $\mathrm{kJ} / \mathrm{mol}$. Colors represent CA isozymes. (B) Compounds $\mathbf{3 b}$ (magenta, PDB ID: 7PP9) and 3d (green, PDB ID: 7PUW) bound to CAXII. (C) Compound $\mathbf{3 b}$ bound to CAXII (green, PDB ID: 7PP9) and CAIX (magenta, PDB ID: 7POM). (D) Compound $3 \mathbf{b}$ bound to CAIX (magenta, PDB ID: 7POM) and mimic-CAIX (green, PDB ID: 7Q0C). Zinc ion is shown as a pink sphere. The notable nonconservative residues between active sites are shown in the "stick" mode. The protein surface of the CA active site is colored orange for hydrophobic residues (V, I, L, F, M, A, G, and P) and gray for the residues with charged and polar side chains ( $, D, N, E, Q, H, K, S, T, Y, W$, and $C$ ).

\subsubsection{Methyl 4-Halo-2-Substituted-5-Sulfamoyl-Benzoates Binding CA Isozymes}

The compounds that contain para- and ortho- substituents are similar in the weak binding affinity to CAI, CAIII, and CAVA. The binding of ortho $\mathbf{3 b}-\mathbf{f}, \mathbf{4 b}$, and para $\mathbf{5 a}-\mathbf{f}, \mathbf{6} \mathbf{a}$, $\mathbf{9 a}-\mathbf{f}$, and $\mathbf{1 0 a}$ was similar to CAII, CAVI, and CAXIII. The affinity of 5a-f (para-sulfanyl) to CAVB was even 10-fold higher than of ortho-substituted $\mathbf{3 b}-\mathbf{e}$, but no significant differences between para-substituted sulfanyl (-S-), 5a-f, 6a, and sulfonyl (-SO $\left.2^{-}\right), \mathbf{9 a}-\mathbf{f}, \mathbf{1 0 a}$, compounds was observed while comparing the intrinsic constants. Thus, only in some cases the oxidation of the sulfanyl group in the para- position had an effect on the affinity for several isozymes, namely, CAVII, CAIX, CAXII, and CAXIV (Figure 1B, lower graph). The binding affinity was quite similar for CAII, CAXII, and other isozymes, containing similar amino acids in the active site.

Comparing the influence of chlorine and bromine, the binding affinities to all CA isozymes were practically identical between compounds $5 \mathbf{a}$ and $\mathbf{6 a}, \mathbf{9 a}$ and $\mathbf{1 0 a}$ (Table 2). The influence of the $\mathrm{R}$ substituent could not be clearly compared, but compounds with more hydrophobic substituents were weaker binders, e.g., $\mathbf{5} \mathbf{d}$ and $\mathbf{5 f}$. This was possibly due to solubility issues that were visually apparent at the highest concentrations used in the experiment. There was a slight trend that the compounds bearing less flexible substituents, $\mathbf{5 a}$ and $\mathbf{5 b}$ or $\mathbf{9 a}$ and $\mathbf{9 b}$, often had higher affinity than $\mathbf{5 c}, \mathbf{5 d}, \mathbf{5 f}$, and $\mathbf{9 c}, \mathbf{9 d}, \mathbf{9 f}$. The greater effect was seen for CAVB going from phenyl to cyclohexyl $(5 \mathbf{a} \rightarrow 5 \mathbf{b}-9.7 \mathrm{~kJ} / \mathrm{mol}$ and $9 \mathbf{a}$ $\rightarrow \mathbf{9 b}-7.4 \mathrm{~kJ} / \mathrm{mol}$ ) in Figure 3A. The affinity similarly decreased in vertical transition for CAIV $(5 a \rightarrow 9 a 8.4 \mathrm{~kJ} / \mathrm{mol}, 5 \mathrm{~b} \rightarrow 9 \mathrm{~b} 9.8 \mathrm{~kJ} / \mathrm{mol}, 5 \mathrm{c} \rightarrow 9 \mathrm{c} 6.5 \mathrm{~kJ} / \mathrm{mol})$, CAIX $(5 \mathrm{~b} \rightarrow 9 \mathrm{~b}$ $1.8 \mathrm{~kJ} / \mathrm{mol}, 5 \mathrm{c} \rightarrow 9 \mathrm{c} 2.5 \mathrm{~kJ} / \mathrm{mol}, 5 \mathrm{~d} \rightarrow \mathbf{9 d} 1.2 \mathrm{~kJ} / \mathrm{mol})$. 
A

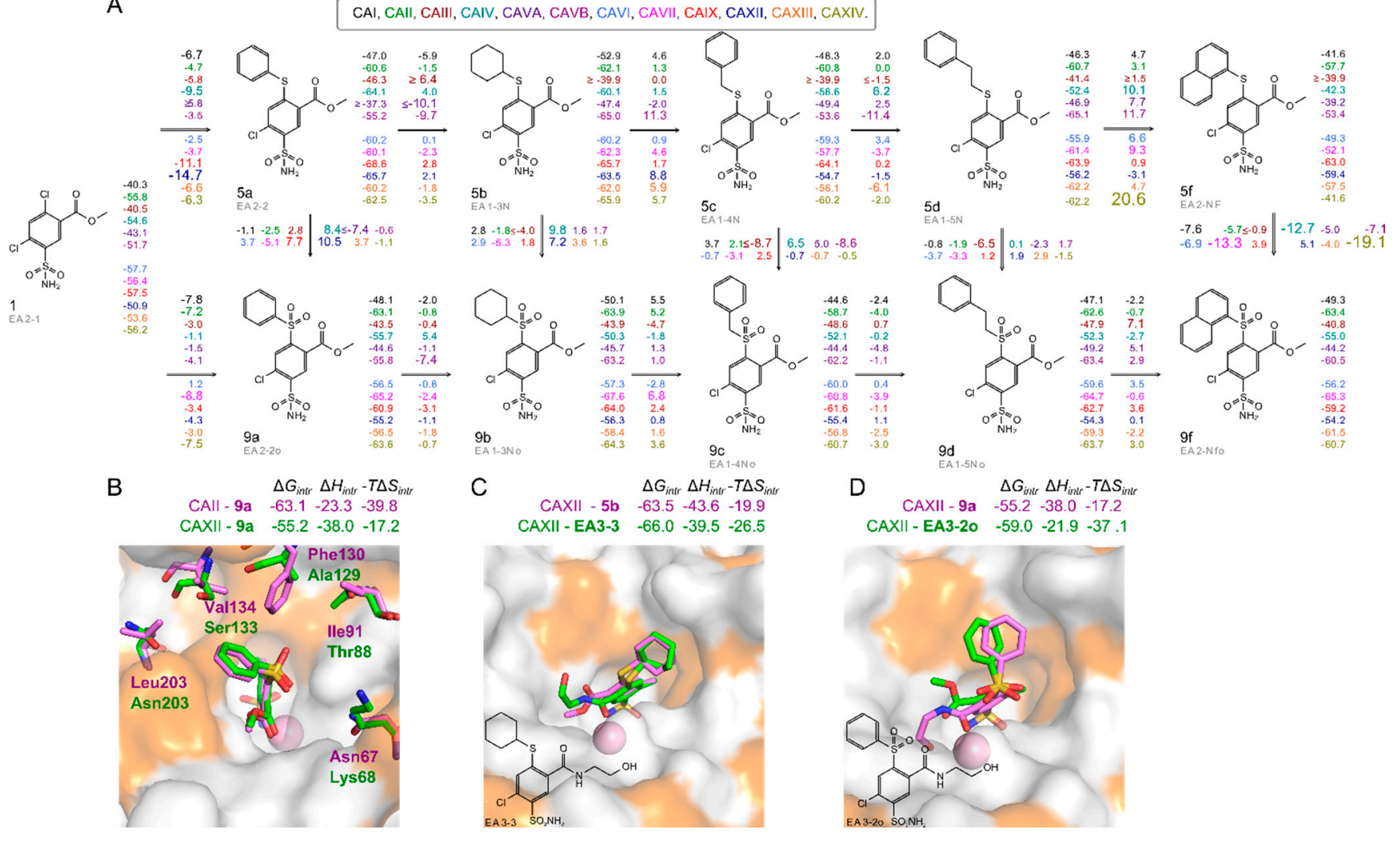

Figure 3. Correlations of compound chemical structures with the changes in the standard intrinsic Gibbs energies of binding and the crystal structures of CAII and CAXII isozymes. (A) Differences of $\Delta G_{\text {intr }}(\mathrm{kJ} / \mathrm{mol})$ between neighboring compounds are listed on the connecting arrows. Colors represent CA isozymes. (B) Compound 9a bound to CAII (PDB ID: 7Q0E) and CAXII (PDB ID: 7PUV). Protein side chains and ligands bound to CAII are colored magenta, CAXII green. The notable nonconservative residues between active sites are shown in the "stick" mode. (C) Compounds $\mathbf{5 b}$ (magenta, PDB ID: 7PUU) and EA3-3 (green, previously studied, PDB ID: 6R6Y) in the active site of CAXII. (D) Compounds 9a (green, PDB ID: 7PUV) and EA3-2o (magenta, previously described, PDB ID: 6R71) in the active site of CAXII. Zinc ion is shown as a pink sphere. The protein surface of the CA active site is colored orange for hydrophobic residues (V, I, L, F, M, A, G, and P) and gray for the residues with charged and polar side chains (R, D, N, E, Q, H, K, S, T, Y, W, and C).

The X-ray crystal structures showed the energetically best pose of the compound when bound to a CA isozyme. Compound 9a was found at an identical position in the active sites of CAII and CAXII (Figure 3B). On the other hand, the binding affinity for CAXII differed from CAII by a factor of $26\left(K_{d \_i n t r}=0.020 \mathrm{nM}\right.$ or $\Delta G_{i n t r}=-63.1 \mathrm{~kJ} / \mathrm{mol}$ for CAII vs. $K_{d \_i n t r}$ $=0.51 \mathrm{nM}$ or $\Delta G_{\text {intr }}=-55.2 \mathrm{~kJ} / \mathrm{mol}$ for CAXII, Table 2 and Figure $\left.3 \mathrm{~B}\right)$. The same binding mode of 9a in CAII and CAXII could be explained by the same interactions between the compound and conservative residues of these active sites. The active site of CAII is more hydrophobic than CAXII (see residues in "stick" mode shown in Figure 3B). For this reason, the binding of this compound to CAII was 26-fold stronger than for CAXII. The interaction of the phenyl group with the hydrophobic side chains was more favorable. The solvation of the ligand during the dissociation process in the presence of a more hydrophobic environment is more difficult. In this case, the stronger interaction was characterized by a lower enthalpy contribution $\left(\Delta H_{\text {intr }}=-23.3 \mathrm{~kJ} / \mathrm{mol}\right.$ to CAII, $\Delta H_{\text {intr }}=-38.0 \mathrm{~kJ} / \mathrm{mol}$ to CAXII, Figure 3B). The structure of $9 \mathbf{a}$ was also determined in the active site of CAI and compared with the positions determined in CAII and CAXII (Figure S4). In this case, the results were somewhat inconclusive because two alternative positions of the compound were found in CAI. One position is partially similar to the positions determined in CAII 
and CAXII, and the alternative is rotated (Figure S4). The 9a is unlikely to occupy a welldefined position and had a weak binding to $\mathrm{CAI}\left(\Delta G_{\text {intr }}=-48.1 \mathrm{~kJ} / \mathrm{mol}\right)$. Still, it showed a significant change in the enthalpy of binding $\left(\Delta H_{\text {intr }}=-39.7 \mathrm{~kJ} / \mathrm{mol}\right)$.

We divided the compounds bound to CAXII into pairs according to their similar binding affinity (Figure 3C,D). Compounds $\mathbf{5 b}$ and EA3-3 in the active site of CAXII were compared in Figure 3C. Compound EA3-3 was described in our previous study [9] and was named " $4 b$ ". The $5 b$ is well defined in the crystal structure (Figure S3D). The binding affinities of the two compounds for CAXII differed by a factor of 2.5, which is insignificant: $K_{d_{-} \text {intr }}=0.020 \mathrm{nM}, \Delta G_{\text {intr }}=-63.5 \mathrm{~kJ} / \mathrm{mol}(5 \mathbf{b})$ and $K_{d_{-} \text {intr }}=0.0080 \mathrm{nM}$, $\Delta G_{\text {intr }}=-66.0 \mathrm{~kJ} / \mathrm{mol}$ (EA3-3). These compounds differ structurally by meta-substituents; EA3-3 has a longer and more flexible substituent $\left(-\mathrm{NH}\left(\mathrm{CH}_{2}\right)_{2} \mathrm{OH}\right)$, but both meta- groups were mostly exposed to the solvent, so they did not contribute much to the positioning in the active site. Both compounds are chlorinated at the ortho- position of the benzenesulfonamide, and chlorine is known to restrict the position of the ligand in the active site [11,20]. In addition, the para-cyclooctyl groups of both compounds occupied the same position. Since the chlorinated compounds had less freedom in the active site, the differences in entropy and enthalpy of the slightly different binding of the meta- groups compensated each other: $\Delta H_{\text {intr }}=-43.6 \mathrm{~kJ} / \mathrm{mol},-T \Delta S_{\text {intr }}=-19.9 \mathrm{~kJ} / \mathrm{mol}(5 \mathbf{b}) \Delta H_{\text {intr }}=-39.5 \mathrm{~kJ} / \mathrm{mol}$, $-T \Delta S_{\text {intr }}=-26.5 \mathrm{~kJ} / \mathrm{mol}($ EA3-3).

The comparison of 9a and EA3-2o bound to CAXII (described in [9] and named "16a") is shown in Figure 3D. Like the previous pair, these compounds differ only by their meta- groups: compound EA3-2o contains $-\mathrm{NH}\left(\mathrm{CH}_{2}\right)_{2} \mathrm{OH}$, while 9a contains - $\mathrm{OCH}_{3}$. The positions of both compounds were not similar in CAXII; the para-benzene rings had slightly different orientations, and they were directed into the center of the active site cavity. Their orientation was defined by the bulky $\mathrm{SO}_{2}$ group of the linker, which was in contact with the protein surface. The EA3-2o bound to CAXII with 3.4-fold greater affinity than 9a $\left(K_{d_{-} i n t r}=0.12 \mathrm{nM}, \Delta G_{\text {intr }}=-59.0 \mathrm{~kJ} / \mathrm{mol}\right.$ vs. $\left.K_{d_{-} \text {intr }}=0.51 \mathrm{nM} \Delta G_{\text {intr }}=-55.2 \mathrm{~kJ} / \mathrm{mol}\right)$. The differences of binding modes between compounds were found in the position of both metaand para-groups, but the different terms of the binding reaction mutually compensated each other: $\Delta H_{\text {intr }}=-38.0 \mathrm{~kJ} / \mathrm{mol},-T \Delta S_{\text {intr }}=-17.2 \mathrm{~kJ} / \mathrm{mol}(9 \mathrm{a}) \Delta H_{\text {intr }}=-21.9 \mathrm{~kJ} / \mathrm{mol}$, $-T \Delta S_{\text {intr }}=-37.1 \mathrm{~kJ} / \mathrm{mol}(\mathbf{E A 3}-2 \mathrm{o})$.

The pairs of compounds bound to the same CA isozyme analyzed in Figures 2D and 3C,D had the following common features: the positions and the binding affinities of the compounds in the pairs were the same or similar. Analogous observations were made previously [21], and such pairs were called "similar" binders. In pairs of "similar" binders, the additional hydrophobic surface did not produce additional interactions with the active site of CA. The possible origin of the entropy-enthalpy compensation was the changes in the solvation-desolvation processes of ligands and the active sites.

Comparison of compound binding to different isozymes when the differences of binding affinities were experimentally significant (Figure 2C,D and Figure 3A) showed some similarities. The compound occupied a similar position in the active site of different isozymes, and the binding of the ligand to a more hydrophobic site was stronger.

2.3.3. Comparison of Methyl Halo 2- and 4-Substituted-5-Sulfamoyl-Benzoates Binding to CA Isozymes

The crystal structures discussed below suggested that the binding interactions between ortho- and para-sulfanyl/sulfonyl compounds with several CA were quite different. Various ortho- and para-substituted compounds had different affinities for CA isozymes. Figure 4A compares the affinity of analogous sulfanyl compounds for CA isozymes, and panels B and $\mathrm{C}$ compare the positions of these compounds in different crystal structures. The transition from $\mathbf{1}$ to $\mathbf{3 b}$ and $\mathbf{5 b}$ shows different changes in affinity and selectivity; compound $\mathbf{3 b}$ bound distinctly more strongly to CAIX $(-17.5 \mathrm{~kJ} / \mathrm{mol})$, CAXII $(-11.4 \mathrm{~kJ} / \mathrm{mol})$, whereas compound $5 \mathbf{b}$ bound more strongly to CAI $(-12.6 \mathrm{~kJ} / \mathrm{mol})$, CAVB $(-13.3 \mathrm{~kJ} / \mathrm{mol})$ and CAXII $(-12.6 \mathrm{~kJ} / \mathrm{mol})$. The influence of the hydrophobic R substituent in the same group 
(transition from left to right $(\rightarrow)$ has already been discussed above, but in some cases, the transition from para- to ortho-positions $(\uparrow)$ showed similar trends and was in all cases favorable only for binding to CAIX. However, a change in the position of more flexible substituents ( $5 \mathrm{c} \rightarrow 3 \mathrm{c}: 2.6 \mathrm{~kJ} / \mathrm{mol}$ and $\mathbf{5 d} \rightarrow 3 \mathrm{~d}: 1.6 \mathrm{~kJ} / \mathrm{mol}$ ) had a lower negative effect on the binding affinity to CAI than a rigid cyclohexyl $(5 \mathbf{b} \rightarrow 3 \mathbf{b}: 8.9 \mathrm{~kJ} / \mathrm{mol})$.

Figure 4B upper part shows 5 superimposed structures: CAXII-EA3-3 (PDB ID: 6R6Y), CAXII-EA3-2o (PDB ID: 6R71), CAXII—5b (PDB ID: 7PUU), CAXII-9a (PDB ID: 7PUV), CAII-9a (PDB ID: 7Q0E); and 4 structures in the lower part: CAXII-3b (PDB ID: 7PP9), CAXII-3d (PDB ID: 7PUW), CAIX-3b (PDB ID: 7POM), mimic CAIX-3b (PDB ID: 7Q0C). Therefore, regardless of the compound, all ortho-compounds occupied a similar position in CAIX and CAXII, and para- occupied another but similar position to each other in CAII and CAXII (Figure 4C,D, respectively). Despite all the differences in the substituents and amino acids in the active sites, the main frame of the compound depicted in the scheme in Figure 4D maintained a similar position. The position of hydrophobic substituents varied, but in the optimal conformation, it was close to the hydrophobic part of the active site. The meta substituents were not analyzed in this study, but a comparison with previously published compounds shows that the hydrophilic substituents in these cases did not result in a different binding mode and were flexible. Thus, the hydrophobic effect plays a key role in enabling the compounds to be in the optimal position. 
A

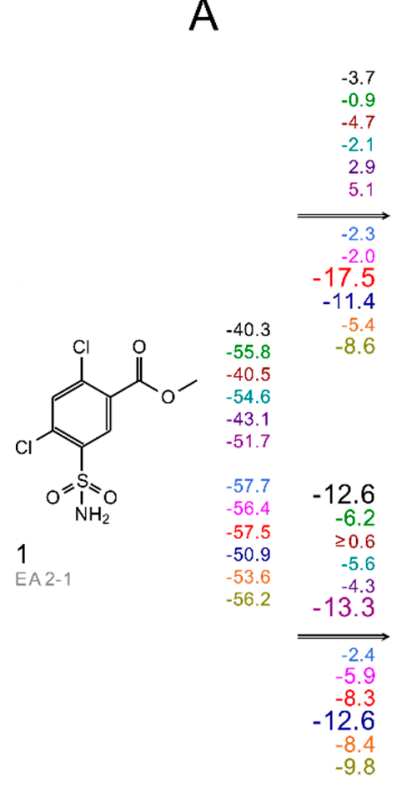

B

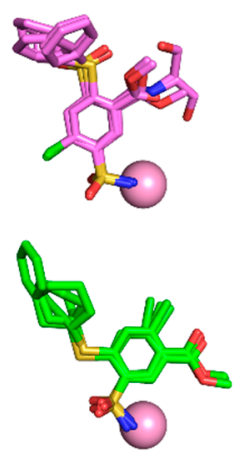

CAI, CAII, CAIII, CAIV, CAVA, CAVB, CAVI, CAVII, CAIX, CAXII, CAXIII, CAXIV.
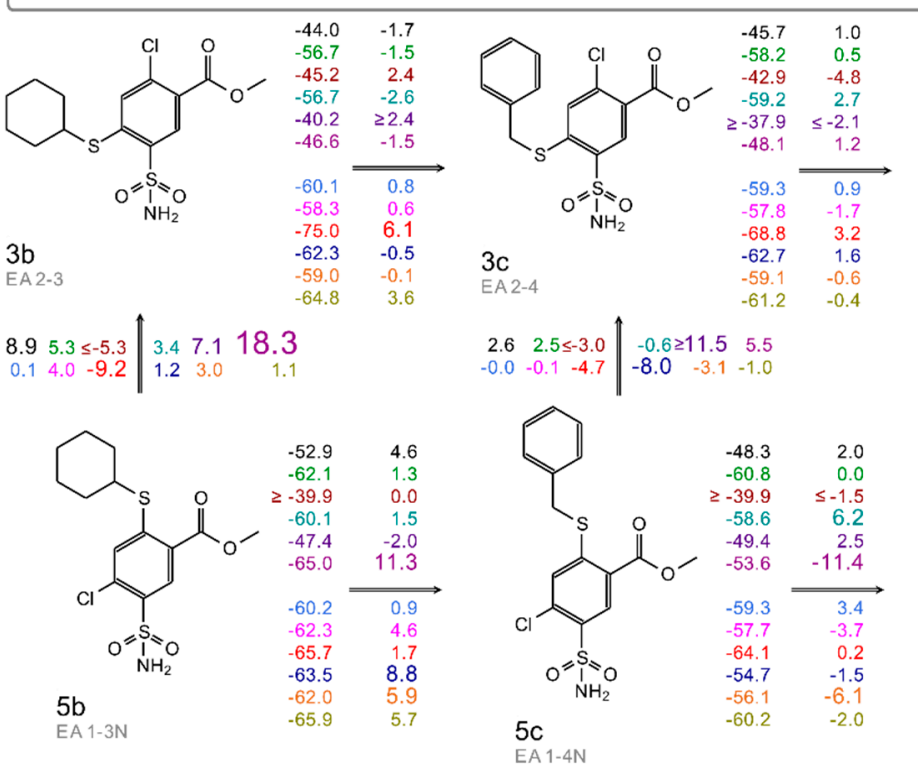

C

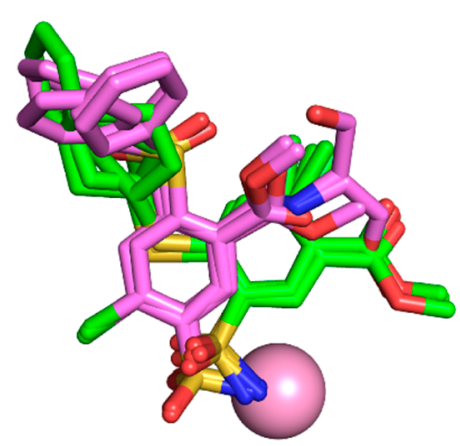

D

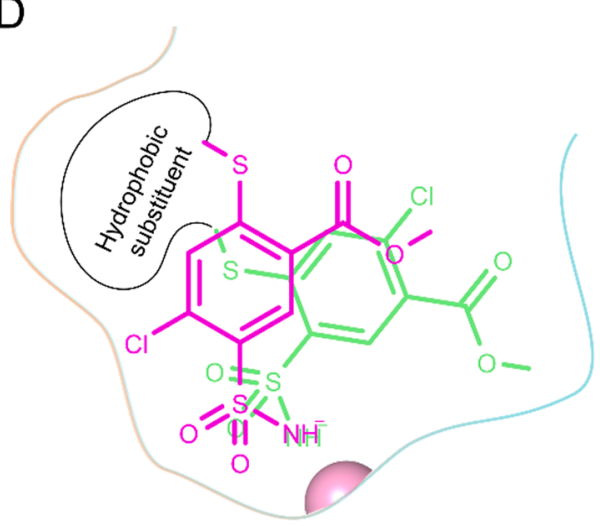

Figure 4. Correlation of compound chemical structures with the changes in standard intrinsic Gibbs energy upon binding and comparison of the crystal structures between CA isozymes. (A) Differences of $\Delta G_{i n t r}(\mathrm{~kJ} / \mathrm{mol})$ between neighboring compounds are listed on the connecting arrows. Colors represent CA isozymes. (B) Superimposed ligands of these crystal structures: (upper panel) parasubstituted ligands are colored magenta: CAXII-3b (PDB ID: 7PP9), CAXII-3d (PDB ID: 7PUW), CAIX-3b (PDB ID: 7POM), mimic-CAIX-3b (PDB ID: 7Q0C), (lower panel) ortho-substituted ligands are colored green: CAXII-EA3-3 (PDB ID: 6R6F), CAXII-EA3-2o (PDB ID: 6R71), CAXII5b (PDB ID: 7PUU), CAXII-9a (PDB ID: 7PUV), CAII-9a (PDB ID: 7Q0E). (C) The abovementioned superimposed structures are shown for comparison. (D) Scheme representing compound position shown in panel C. Orange line represents more hydrophobic side of the active site. Zinc ion is shown as a pink sphere.

\section{Conclusions}

We have designed a series of compounds and investigated the effect of substituents and their positions in methyl halo 2- and 4-substituted-5-sulfamoyl-benzoate binding to human CA isozymes. The sulfanyl (-S) and sulfonyl $\left(-\mathrm{SO}_{2}^{-}\right)$substituents of different sizes and hydrophobicity were examined in greater detail. We provided a crystallographic position of these two groups of compounds bound in the active sites of CA. Although there were differences in the orientation of the substituents and the thermodynamic parameters, the positions in the same group of compounds remained similar among CA isozymes.

The strongest binding ortho-sulfanyl-substituted benzenesulfonamides, especially compounds $3 \mathbf{b}$ and $\mathbf{4 b}$, showed extremely high femtomolar intrinsic affinity (80 fM, cor- 
responding to very high, $120 \mathrm{pM}$ observed affinity) and selectivity for tumor-associated CAIX. Meanwhile, analogous sulfonyl compounds bound weakly. Other para-substituted compounds had completely different binding profiles and bound similarly to several CA isozymes not demonstrating such selectivity.

The crystal structures of the complexes containing compounds bound to CAI, CAII, mimic-CAIX (mutant of CAII ${ }^{A 65 S, ~ N 67 Q, ~ I 91 L, ~ F 130 V, ~ V 134 L, ~ L 203 A), ~ C A I X, ~ a n d ~ C A X I I ~ p r o v i d e d ~ a ~}$ broader understanding of the differences and similarities in the thermodynamic parameters of binding. We observed a tendency that interaction, where there was a higher contribution of the hydrophobic effect and higher entropy contribution, usually also had a higher affinity. This may be explained by the fact that (i) the hydrophobic side chains and bulky hydrophobic substituents of the ligand prevented water molecules from entering the cavity, leading to stronger interaction, and (ii) the water molecules could penetrate between the ligand and the active site cavity through the hydrophilic surface part of the active site. Water molecules in the deeper part of the active site could compete with the compound and cause weaker interaction than in the first case.

\section{Materials and Methods}

\subsection{Organic Synthesis}

All starting materials and reagents were commercial products and were used without further purification. Melting points of the compounds were determined in open capillaries on a Thermo Scientific 9100 Series and are uncorrected. ${ }^{1} \mathrm{H}$ and ${ }^{13} \mathrm{C}$ NMR spectra were recorded on a (400 and $100 \mathrm{MHz}$, respectively) spectrometer in DMSO- $\mathrm{d}_{6}$ using residual DMSO signals (2.52 ppm and $40.21 \mathrm{ppm}$ for ${ }^{1} \mathrm{H}$ and ${ }^{13} \mathrm{C}$ NMR spectra, respectively) as the internal standard. TLC was performed with silica gel 60 F254 aluminum plates (Merck) and visualized with UV light. Column chromatography was performed using silica gel 60 (0.040-0.063 mm, Merck). High-resolution mass spectra (HRMS) were recorded on a Dual-ESI Q-TOF 6520 mass spectrometer (Agilent Technologies). The purity of final compounds was verified by HPLC to be $>95 \%$ using the Agilent 1290 Infinity instrument with a Poroshell 120 SB-C18 $(2.1 \mathrm{~mm} \times 100 \mathrm{~mm}, 2.7 \mu \mathrm{m})$ reversed-phase column. Analytes were eluted using a linear gradient of water/methanol $(20 \mathrm{mM}$ ammonium formate in both phases) from 60:40 to 30:70 over $12 \mathrm{~min}$, then from 30:70 to 20:80 over $1 \mathrm{~min}$, and then 20:80 over $5 \mathrm{~min}$ at a flow rate of $0.2 \mathrm{~mL} / \mathrm{min}$. UV detection was at $254 \mathrm{~nm}$.

\subsection{General Procedure for the Syntheses of 1, 2}

The appropriate 2,4-dichloro-5-sulfamoylbenzoic acid or 2,4-dibromo-5-sulfamoylbenzoic acid [8] $(10.0 \mathrm{mmol})$ was refluxed in $\mathrm{MeOH}(100 \mathrm{~mL})$ with concentrated $\mathrm{H}_{2} \mathrm{SO}_{4}(1 \mathrm{~mL})$ for $20 \mathrm{~h}$. The reaction mixture was concentrated under reduced pressure.

Methyl 2,4-dichloro-5-sulfamoyl-benzoate (1, EA2-1). Recrystallization was accomplished from MeOH. Yield: $2.70 \mathrm{~g}, 95 \%, \operatorname{mp} 202{ }^{\circ} \mathrm{C} .{ }^{1} \mathrm{H}$ NMR $\delta$ ppm: $3.91\left(3 \mathrm{H}, \mathrm{s}, \mathrm{CH}_{3}\right), 7.87(2 \mathrm{H}$, s, $\left.\mathrm{SO}_{2} \mathrm{NH}_{2}\right), 8.04\left(1 \mathrm{H}, \mathrm{s}, \mathrm{C}_{3}-\mathrm{H}\right), 8.40\left(1 \mathrm{H}, \mathrm{s}, \mathrm{C}_{6}-\mathrm{H}\right) .{ }^{13} \mathrm{C}$ NMR $\delta$ ppm: 53.5, 128.8, 131.7, $134.0,135.0,136.8,140.5,164.1$. HRMS calculated for $\mathrm{C}_{8} \mathrm{H}_{7} \mathrm{Cl}_{2} \mathrm{NO}_{4} \mathrm{~S}\left[(\mathrm{M}+\mathrm{H})^{+}\right]: 283.9546$, found: 283.9546.

Methyl 2,4-dibromo-5-sulfamoyl-benzoate (2, LJ14-4). Recrystallization was accomplished from MeOH. Yield: $2.35 \mathrm{~g}, 63 \%$, mp 201-203 ${ }^{\circ} \mathrm{C} .{ }^{1} \mathrm{H}$ NMR $\delta$ ppm: $3.90\left(3 \mathrm{H}, \mathrm{s}, \mathrm{CH}_{3}\right), 7.84$ $\left(2 \mathrm{H}, \mathrm{s}, \mathrm{SO}_{2} \mathrm{NH}_{2}\right), 8.33\left(1 \mathrm{H}, \mathrm{s}, \mathrm{C}_{6}-\mathrm{H}\right), 8.35\left(1 \mathrm{H}, \mathrm{s}, \mathrm{C}_{3}-\mathrm{H}\right) .{ }^{13} \mathrm{C} \mathrm{NMR} \delta \mathrm{ppm}: 53.6,123.6,125.2$, $131.3,131.6,140.2,142.8,164.9$. HRMS calculated for $\mathrm{C}_{8} \mathrm{H}_{7} \mathrm{Br}_{2} \mathrm{NO}_{4} \mathrm{~S}\left[(\mathrm{M}+\mathrm{H})^{+}\right]: 373.8515$ (100\%), found: $373.8514(100 \%)$.

\subsection{General Procedure for the Syntheses of $\mathbf{3 b}, \mathbf{3 e}$, and $\mathbf{4 b}$}

The mixture of appropriate methyl 2,4-dihalogeno-5-sulfamoylbenzoate (compounds 1,2) $(1.00 \mathrm{mmol}), \mathrm{DMSO}(2 \mathrm{~mL})$, appropriate cyclohexanethiol or cyclododecanethiol $(1.10 \mathrm{mmol})$, and $\mathrm{K}_{2} \mathrm{CO}_{3}(553 \mathrm{mg}, 4.00 \mathrm{mmol})$ was heated at $60{ }^{\circ} \mathrm{C}$ temperature for $4-6 \mathrm{~h}$. The mixture was cooled to room temperature, and brine was added. The product was 
extracted with EtOAc $(3 \times 7 \mathrm{~mL})$. The organic layer was washed with $\mathrm{H}_{2} \mathrm{O}$, dried over anhydrous $\mathrm{MgSO}_{4}$, filtered, and concentrated.

Methyl 2-chloro-4-(cyclohexylsulfanyl)-5-sulfamoylbenzoate (3b, EA2-3). The product was purified by chromatography on a column of silica gel with $\mathrm{CHCl}_{3}: \mathrm{EtOAc}(10: 1), \mathrm{R}_{\mathrm{f}}=0.40$. Yield: $131 \mathrm{mg}, 36 \%, \mathrm{mp} 112-114{ }^{\circ} \mathrm{C} .{ }^{1} \mathrm{H}$ NMR $\delta$ ppm: $1.21-1.31(1 \mathrm{H}, \mathrm{m}, \mathrm{Cy}-\mathrm{H}), 1.38-1.50$ (4H, m, Cy-H), 1.60-1.63 (1H, m, Cy-H), 1.70-1.77 (2H, m, Cy-H), 1.93-2.01 (2H, m, Cy-H), 3.71-3.77 (1H, m, Cy-H), $3.88\left(3 \mathrm{H}, \mathrm{s}, \mathrm{CH}_{3}\right), 7.56\left(2 \mathrm{H}, \mathrm{s}, \mathrm{SO}_{2} \mathrm{NH}_{2}\right), 7,71\left(1 \mathrm{H}, \mathrm{s}, \mathrm{C}_{3}-\mathrm{H}\right), 8.33$ $\left(1 \mathrm{H}, \mathrm{s}, \mathrm{C}_{6}-\mathrm{H}\right) .{ }^{13} \mathrm{C}$ NMR $\delta$ ppm: 25.6, 25.7, 32.4, 44.3, 53.2, 125.1, 130.3, 131.5, 136.4, 140.2, 142.9, 164.4. HRMS calculated. for $\mathrm{C}_{14} \mathrm{H}_{18} \mathrm{ClNO}_{4} \mathrm{~S}_{2}\left[(\mathrm{M}+\mathrm{H})^{+}\right]$: 364.0439 , found: 364.0440 .

Methyl 2-chloro-4-(cyclododecylsulfanyl)-5-sulfamoylbenzoate (3e, EA2-12). The product was purified by chromatography on a column of silica gel with $\mathrm{CHCl}_{3}$ : $\mathrm{EtOAc}(5: 1), \mathrm{R}_{\mathrm{f}}=0.65$, then recrystallization was accomplished from toluene:EtOAc (8:1). Yield: $210 \mathrm{mg}$, 47\%, mp $185-187{ }^{\circ} \mathrm{C} .{ }^{1} \mathrm{H}$ NMR $\delta$ ppm: $1.25-1.64(20 \mathrm{H}, \mathrm{m}$, cyclododecyl-H), $1.71-1.83(2 \mathrm{H}$, $\mathrm{m}$, cyclododecyl-H), 3.71-3.79 $\left(1 \mathrm{H}, \mathrm{m}\right.$, cyclododecyl-H), $3.88\left(3 \mathrm{H}, \mathrm{s}, \mathrm{CH}_{3}\right), 7.56(2 \mathrm{H}, \mathrm{s}$, $\left.\mathrm{SO}_{2} \mathrm{NH}_{2}\right), 7.67\left(1 \mathrm{H}, \mathrm{s}, \mathrm{C}_{3}-\mathrm{H}\right), 8.33\left(1 \mathrm{H}, \mathrm{s}, \mathrm{C}_{6}-\mathrm{H}\right) .{ }^{13} \mathrm{C} \mathrm{NMR} \delta$ ppm: 22.1, 23.3, 23.4, 23.8, 24.1, 29.2, 43.2, 53.2, 124.9, 130.3, 131.4, 136.3, 140.3, 143.5, 164.4. HRMS calculated for $\mathrm{C}_{20} \mathrm{H}_{30} \mathrm{ClNO}_{4} \mathrm{~S}_{2}\left[(\mathrm{M}+\mathrm{H})^{+}\right]$: 448.1378 , found: 448.1370 .

Methyl 2-bromo-4-(cyclohexylsulfanyl)-5-sulfamoylbenzoate (4b, LJ15-12). The product was purified by chromatography on a column of silica gel with $\mathrm{CHCl}_{3}: \mathrm{EtOAc}(15: 1), \mathrm{R}_{\mathrm{f}}=0.29$. Yield: $180 \mathrm{mg}, 44 \%$, mp $123-125{ }^{\circ} \mathrm{C} .{ }^{1} \mathrm{H}$ NMR $\delta \mathrm{ppm}: 1.24-1.31(1 \mathrm{H}, \mathrm{m}, \mathrm{Cy}-\mathrm{H}), 1.38-1.50$ $(4 \mathrm{H}, \mathrm{m}, \mathrm{Cy}-\mathrm{H}), 1.60-1.63(1 \mathrm{H}, \mathrm{m}, \mathrm{Cy}-\mathrm{H}), 1.70-1.75(2 \mathrm{H}, \mathrm{m}, \mathrm{Cy}-\mathrm{H}), 1.95-1.97(2 \mathrm{H}, \mathrm{m}, \mathrm{Cy}-\mathrm{H})$, 3.72-3.77 (1H, m, Cy-H), $3.88\left(3 \mathrm{H}, \mathrm{s}, \mathrm{CH}_{3}\right), 7.54\left(2 \mathrm{H}, \mathrm{s}, \mathrm{SO}_{2} \mathrm{NH}_{2}\right), 7.85\left(1 \mathrm{H}, \mathrm{s}, \mathrm{C}_{6}-\mathrm{H}\right), 8.27(1 \mathrm{H}$, s, $\left.\mathrm{C}_{3}-\mathrm{H}\right) .{ }^{13} \mathrm{C}$ NMR $\delta$ ppm: 25.6, 25.7, 32.4, 44.5, 53.2, 125.1, 127.5, 131.0, 133.6, 140.1, 142.5, 165.0. HRMS calculated for $\mathrm{C}_{14} \mathrm{H}_{18} \mathrm{BrNO}_{4} \mathrm{~S}_{2}\left[(\mathrm{M}+\mathrm{H})^{+}\right]$: $409.9913(100 \%)$, found: 409.9915 $(100 \%)$.

\subsection{General Procedure for the Syntheses of $\mathbf{3 c}$ and $\mathbf{3 d}$}

The mixture of methyl 2,4-dichloro-5-sulfamoylbenzoate (1) $(284 \mathrm{mg}, 1.00 \mathrm{mmol})$, DMSO (2 mL), appropriate phenylmethanethiol or 2-phenylethanethiol $(1.10 \mathrm{mmol})$, and TEA $(121 \mathrm{mg}, 1.20 \mathrm{mmol})$ was heated at $50{ }^{\circ} \mathrm{C}$ temperature for $6-12 \mathrm{~h}$. The progress of the reaction was monitored by TLC. The mixture was cooled to room temperature, and brine was added. The product was extracted with EtOAc $(3 \times 7 \mathrm{~mL})$. The organic layer was washed with $\mathrm{H}_{2} \mathrm{O}$, dried over anhydrous $\mathrm{MgSO}_{4}$, filtered, and concentrated.

Methyl 4-(benzylsulfanyl)-2-chloro-5-sulfamoylbenzoate (3c, EA2-4). The product was purified by chromatography on a column of silica gel with $\mathrm{CHCl}_{3}: \mathrm{EtOAc}(4: 1), \mathrm{R}_{\mathrm{f}}=0.48$. Yield: $119 \mathrm{mg}, 32 \%, \mathrm{mp} 125-126^{\circ} \mathrm{C} .{ }^{1} \mathrm{H}$ NMR $\delta \mathrm{ppm}: 3.87\left(3 \mathrm{H}, \mathrm{s}, \mathrm{CH}_{3}\right), 4.50\left(2 \mathrm{H}, \mathrm{s}, \mathrm{CH}_{2}\right)$, $7.29(1 \mathrm{H}, \mathrm{t}, J=7.2 \mathrm{~Hz}, \mathrm{Ph}-\mathrm{H}), 7.36(2 \mathrm{H}, \mathrm{t}, J=7.2 \mathrm{~Hz}, \mathrm{Ph}-\mathrm{H}), 7.51(2 \mathrm{H}, \mathrm{d}, J=7.2 \mathrm{~Hz}, \mathrm{Ph}-\mathrm{H})$, $7.64\left(2 \mathrm{H}, \mathrm{s}, \mathrm{SO}_{2} \mathrm{NH}_{2}\right), 7.69\left(1 \mathrm{H}, \mathrm{s}, \mathrm{C}_{3}-\mathrm{H}\right), 8.31\left(1 \mathrm{H}, \mathrm{s}, \mathrm{C}_{6}-\mathrm{H}\right) .{ }^{13} \mathrm{C}$ NMR $\delta$ ppm: 36.3, 53.2, $124.9,128.0,129.1,129.2,129.8,131.3,135.8,136.4,139.1,143.7,164.3$. HRMS calculated for $\mathrm{C}_{15} \mathrm{H}_{14} \mathrm{ClNO}_{4} \mathrm{~S}_{2}\left[(\mathrm{M}+\mathrm{H})^{+}\right]$]: 372.0126, found: 372.0125 .

Methyl 2-chloro-4-[(2-phenylethyl)sulfanyl]-5-sulfamoylbenzoate (3d, EA2-5). The product was purified by chromatography on a column of silica gel with $\mathrm{CHCl}_{3}: \mathrm{EtOAc}(5: 1), \mathrm{R}_{\mathrm{f}}=$ 0.67. Yield: $97 \mathrm{mg}, 25 \%$, mp $111-112{ }^{\circ} \mathrm{C} .{ }^{1} \mathrm{H}$ NMR $\delta \mathrm{ppm}: 2.97\left(2 \mathrm{H}, \mathrm{t}, J=7.6 \mathrm{~Hz}, \mathrm{CH}_{2} \mathrm{Ph}\right)$, $3.46\left(2 \mathrm{H}, \mathrm{t}, J=7.6 \mathrm{~Hz}, \mathrm{CH}_{2} \mathrm{~S}\right), 3.88\left(3 \mathrm{H}, \mathrm{s}, \mathrm{CH}_{3}\right), 7.23(1 \mathrm{H}, \mathrm{m}, \mathrm{Ph}-\mathrm{H}), 7.29-7.33(4 \mathrm{H}, \mathrm{m}, \mathrm{Ph}-\mathrm{H})$, $7.59\left(2 \mathrm{H}, \mathrm{s}, \mathrm{SO}_{2} \mathrm{NH}_{2}\right), 7.65\left(1 \mathrm{H}, \mathrm{s}, \mathrm{C}_{3}-\mathrm{H}\right), 8.31\left(1 \mathrm{H}, \mathrm{s}, \mathrm{C}_{6}-\mathrm{H}\right) .{ }^{13} \mathrm{C}$ NMR $\delta$ ppm: 33.3, 34.1, $53.2,124.8,126.9,128.9,129.1,129.2,131.2,136.5,139.4,140.0,143.9,164.4$. HRMS calculated for $\mathrm{C}_{16} \mathrm{H}_{16} \mathrm{ClNO}_{4} \mathrm{~S}_{2}\left[(\mathrm{M}+\mathrm{H})^{+}\right]$: 386.0282 , found: 386.0282 .

\subsection{General Procedure for the Syntheses of $\mathbf{5 a}, \mathbf{5 f}$, and $\mathbf{6 a}$}

The mixture of appropriate 2,4-dihalogeno-5-sulfamoylbenzoate (compounds 1,2) $(1.00 \mathrm{mmol}), \mathrm{MeOH}(5 \mathrm{~mL})$, thiophenol or 1-thionaphthol $(1.10 \mathrm{mmol}$ ) and TEA (121 mg, $1.20 \mathrm{mmol}$ ) was refluxed for 2-6 $\mathrm{h}$. $\mathrm{MeOH}$ was evaporated under reduced pressure, and the resultant precipitate was washed with $\mathrm{H}_{2} \mathrm{O}$. 
Methyl 4-chloro-2-(phenylsulfanyl)-5-sulfamoylbenzoate (5a, EA2-2). The product was purified by chromatography on a column of silica gel with $\mathrm{CHCl}_{3}$ :EtOAc (10:1), $\mathrm{R}_{\mathrm{f}}=0.32$. Yield: $161 \mathrm{mg}, 45 \%, \mathrm{mp} 223-226{ }^{\circ} \mathrm{C} .{ }^{1} \mathrm{H}$ NMR $\delta$ ppm: $3.94\left(3 \mathrm{H}, \mathrm{s}, \mathrm{CH}_{3}\right), 6.68\left(1 \mathrm{H}, \mathrm{s}, \mathrm{C}_{3}-\mathrm{H}\right)$, 7.62-7.67 (5H, m, Ph-H), $7.74\left(2 \mathrm{H}, \mathrm{s}, \mathrm{SO}_{2} \mathrm{NH}_{2}\right), 8.50\left(1 \mathrm{H}, \mathrm{s}, \mathrm{C}_{6}-\mathrm{H}\right) .{ }^{13} \mathrm{C}$ NMR $\delta$ ppm: 53.3, 124.3, 128.7, 130.1, 131.2 (2C), 131.8, 135.2, 136.2, 137.5, 149.6, 164.8. HRMS calculated for $\mathrm{C}_{14} \mathrm{H}_{12} \mathrm{ClNO}_{4} \mathrm{~S}_{2}\left[(\mathrm{M}+\mathrm{H})^{+}\right]$: 357.9969, found: 357.9970 .

Methyl 4-chloro-2-(1-naphthylsulfanyl)-5-sulfamoyl-benzoate (5f, EA2-NF). The product was purified by chromatography on a column of silica gel with $\mathrm{CHCl}_{3}$ :EtOAc $(5: 1), \mathrm{R}_{\mathrm{f}}=0.77$. Yield: $265 \mathrm{mg}, 65 \%, \mathrm{mp} 235-237{ }^{\circ} \mathrm{C} .{ }^{1} \mathrm{H}$ NMR $\delta$ ppm: $3.99\left(3 \mathrm{H}, \mathrm{s}, \mathrm{CH}_{3}\right), 6.34(1 \mathrm{H}, \mathrm{s}, \mathrm{C}-\mathrm{H})$, 7.61-7.68 (2H, m, Naph-H), $7.70\left(2 \mathrm{H}, \mathrm{s}, \mathrm{SO}_{2} \mathrm{NH}_{2}\right), 7.71-7.74(1 \mathrm{H}, \mathrm{m}, \mathrm{Naph}-\mathrm{H}), 8.04(1 \mathrm{H}$, dd, $J=7.2 \mathrm{~Hz}, J=1.2 \mathrm{~Hz}$, Naph-H), 8.08-8.15 (2H, m, Naph-H), $8.26(1 \mathrm{H}, \mathrm{d}, J=8.4 \mathrm{~Hz}$, Naph-H), 8.54 (1H, s, C 6 -H). ${ }^{13} \mathrm{C}$ NMR $\delta$ ppm: 53.4, 124.3, 125.0, 126.7, 127.2, 127.6, 128.5, $128.8,129.8,132.0,132.6,133.8,134.6,135.1,136.9,137.5,148.9,164.9$. HRMS calculated for $\mathrm{C}_{18} \mathrm{H}_{14} \mathrm{ClNO}_{4} \mathrm{~S}_{2}\left[(\mathrm{M}+\mathrm{H})^{+}\right]: 408.0126$, found: 408.0131 .

Methyl 4-bromo-2-(phenylsulfanyl)-5-sulfamoylbenzoate (6a, LJ15-11). The product was purified by chromatography on a column of silica gel with $\mathrm{CHCl}_{3}$ :EtOAc $(15: 1), \mathrm{R}_{\mathrm{f}}=0.20$, then recrystallization was accomplished from toluene. Yield: $145 \mathrm{mg}, 36 \%, \mathrm{mp} 202-204{ }^{\circ} \mathrm{C}$. ${ }^{1} \mathrm{H}$ NMR $\delta$ ppm: $3.93\left(3 \mathrm{H}, \mathrm{s}, \mathrm{CH}_{3}\right), 6.89\left(1 \mathrm{H}, \mathrm{s}, \mathrm{C}_{3}-\mathrm{H}\right), 7.58-7,63(5 \mathrm{H}, \mathrm{m}, \mathrm{Ph}-\mathrm{H}), 7.71(2 \mathrm{H}$, $\left.\mathrm{s}, \mathrm{SO}_{2} \mathrm{NH}_{2}\right), 8.52\left(1 \mathrm{H}, \mathrm{s}, \mathrm{C}_{6}-\mathrm{H}\right) .{ }^{13} \mathrm{C} \mathrm{NMR} \delta$ ppm: 53.3, 124.3, 124.8, 130.2, 131.1(2C), 131.7, $132.3,136.1,139.3,149.2,165.0$. HRMS calculated for $\mathrm{C}_{14} \mathrm{H}_{12} \mathrm{BrNO}_{4} \mathrm{~S}_{2}\left[(\mathrm{M}+\mathrm{H})^{+}\right]: 403.9443$ (100\%), found: $403.9437(100 \%)$.

\subsection{General Procedure for the Syntheses of $\mathbf{7 b}-\mathbf{d}, \mathbf{8 b}, \mathbf{9 a}-\mathbf{d}, \mathbf{9 f}, \mathbf{1 0 a}$}

The $30 \% \mathrm{H}_{2} \mathrm{O}_{2}$ (aq) (1.50 mmol, $0.148 \mathrm{~mL}$ ) was added to a solution of appropriate benzenesulfonamide (compounds $\mathbf{3 b}-\mathbf{d}, \mathbf{4 b}, \mathbf{5 a}-\mathbf{d}, \mathbf{f}, \mathbf{6 a})(0.500 \mathrm{mmol})$ in $\mathrm{AcOH}(1.7 \mathrm{~mL})$ at $70{ }^{\circ} \mathrm{C}$ and allowed stirring for $2-3 \mathrm{~h}$. The solvent was removed under reduced pressure, and the resultant precipitate was washed with $\mathrm{H}_{2} \mathrm{O}$.

Methyl 2-chloro-4-cyclohexylsulfonyl-5-sulfamoylbenzoate (7b, EA2-3o). Yield: $164 \mathrm{mg}$, 83\%, mp 184-187 ${ }^{\circ} \mathrm{C} .{ }^{1} \mathrm{H}$ NMR $\delta$ ppm: 1.14-1.21 (3H, m, Cy-H), 1.42-1.50 (2H, m, Cy-H), $1.63\left(1 \mathrm{H}\right.$, br s, Cy-H), 1.81-1.87 (4H, m, Cy-H), 3.89-3.92 (1H, m, Cy-H), $3.96\left(3 \mathrm{H}, \mathrm{s}, \mathrm{CH}_{3}\right)$, $7.48\left(2 \mathrm{H}, \mathrm{s}, \mathrm{SO}_{2} \mathrm{NH}_{2}\right), 8.11\left(1 \mathrm{H}, \mathrm{s}, \mathrm{C}_{3}-\mathrm{H}\right), 8.57\left(1 \mathrm{H}, \mathrm{s}, \mathrm{C}_{6}-\mathrm{H}\right) .{ }^{13} \mathrm{C}$ NMR $\delta$ ppm: 24.9 (2C), 25.1, $53.9,62.2,133.3,135.1,135.5,136.7,138.6,142.1,163.9$. HRMS calculated for $\mathrm{C}_{14} \mathrm{H}_{18} \mathrm{ClNO}_{6} \mathrm{~S}_{2}$ $\left[(\mathrm{M}+\mathrm{H})^{+}\right]:$396.0337, found: 396.0336 .

Methyl 4-benzylsulfonyl-2-chloro-5-sulfamoylbenzoate (7c, EA2-4o). Recrystallization was accomplished from MeOH. Yield: $123 \mathrm{mg}, 61 \%$, mp 154-156 ${ }^{\circ} \mathrm{C} .{ }^{1} \mathrm{H}$ NMR $\delta$ ppm: 3.95 $\left(3 \mathrm{H}, \mathrm{s}, \mathrm{CH}_{3}\right), 5.04\left(2 \mathrm{H}, \mathrm{s}, \mathrm{CH}_{2}\right), 7.24-7.26(2 \mathrm{H}, \mathrm{m}, \mathrm{Ph}-\mathrm{H}), 7.33-7.40(3 \mathrm{H}, \mathrm{m}, \mathrm{Ph}-\mathrm{H}), 7.58$ $\left(2 \mathrm{H}, \mathrm{s}, \mathrm{SO}_{2} \mathrm{NH}_{2}\right), 7.77\left(1 \mathrm{H}, \mathrm{s}, \mathrm{C}_{3}-\mathrm{H}\right), 8.57\left(1 \mathrm{H}, \mathrm{s}, \mathrm{C}_{6}-\mathrm{H}\right) .{ }^{13} \mathrm{C}$ NMR $\delta$ ppm: 53.9, 60.9, 127.5, $129.1,129.5,131.7,132.9,135.0,135.4,136.3,139.2,142.0,163.8$. HRMS calculated for $\mathrm{C}_{15} \mathrm{H}_{14} \mathrm{ClNO}_{6} \mathrm{~S}_{2}\left[(\mathrm{M}+\mathrm{H})^{+}\right]: 404.0024$, found: 404.0023 .

Methyl 2-chloro-4-(2-phenylethylsulfonyl)-5-sulfamoylbenzoate (7d, EA2-5o). Recrystallization was accomplished from MeOH. Yield: $161 \mathrm{mg}, 77 \%, \mathrm{mp} 132-134{ }^{\circ} \mathrm{C} .{ }^{1} \mathrm{H}$ NMR $\delta \mathrm{ppm}$ : $3.03\left(2 \mathrm{H}, \mathrm{t}, J=7.8 \mathrm{~Hz}, \mathrm{CH}_{2}\right), 3.95\left(3 \mathrm{H}, \mathrm{s}, \mathrm{CH}_{3}\right), 4.08\left(2 \mathrm{H}, \mathrm{t}, J=7.8 \mathrm{~Hz}, \mathrm{CH}_{2}\right), 7.13-7.27(5 \mathrm{H}$, $\mathrm{m}, \mathrm{Ph}-\mathrm{H}), 7.50\left(2 \mathrm{H}, \mathrm{s}, \mathrm{SO}_{2} \mathrm{NH}_{2}\right), 8.07\left(1 \mathrm{H}, \mathrm{s}, \mathrm{C}_{3}-\mathrm{H}\right), 8.49\left(1 \mathrm{H}, \mathrm{s}, \mathrm{C}_{6}-\mathrm{H}\right) .{ }^{13} \mathrm{C}$ NMR $\delta \mathrm{ppm}:$ 28.0, 53.9, 55.8, 127.1, 128.9(2C), 132.8, 135.0, 135.3, 136.7, 137.7, 140.0, 141.6, 163.9. HRMS calculated for $\mathrm{C}_{16} \mathrm{H}_{16} \mathrm{ClNO}_{6} \mathrm{~S}_{2}\left[(\mathrm{M}+\mathrm{H})^{+}\right]$: 418.0180, found: 418.0175 .

Methyl 2-bromo-4-cyclohexylsulfonyl-5-sulfamoylbenzoate (8b, LJ15-12o). Yield: $172 \mathrm{mg}$, 78\%, mp 217-219 ${ }^{\circ} \mathrm{C} .{ }^{1} \mathrm{H}$ NMR $\delta$ ppm: 1.16-1.24 (3H, m, Cy-H), 1.42-1.50 (2H, m, Cy$\mathrm{H}), 1.57-1.63$ (1H, m, Cy-H), 1.79-1.86 (4H, m, Cy-H), 3.89-3.92 (1H, m, Cy-H), 3.95 (3H, $\left.\mathrm{s}, \mathrm{CH}_{3}\right), 7.47\left(2 \mathrm{H}, \mathrm{s}, \mathrm{SO}_{2} \mathrm{NH}_{2}\right), 8.25\left(1 \mathrm{H}, \mathrm{s}, \mathrm{C}_{3}-\mathrm{H}\right), 8.50\left(1 \mathrm{H}, \mathrm{s}, \mathrm{C}_{6}-\mathrm{H}\right) .{ }^{13} \mathrm{C} \mathrm{NMR} \delta \mathrm{ppm}$ : 24.9(2C), 25.1, 53.9, 62.2, 125.3, 132.8, 137.7, 138.1, 138.4, 142.6, 164.6. HRMS calculated for $\mathrm{C}_{14} \mathrm{H}_{18} \mathrm{BrNO}_{6} \mathrm{~S}_{2}\left[(\mathrm{M}+\mathrm{H})^{+}\right]: 441.9811(100 \%)$, found: $441.9806(100 \%)$.

Methyl 2-(benzenesulfonyl)-4-chloro-5-sulfamoylbenzoate (9a, EA2-2No). The product was purified by chromatography on a column of silica gel with $\mathrm{CHCl}_{3}$ :EtOAc $(4: 1), \mathrm{R}_{\mathrm{f}}=0.33$. Yield: $158 \mathrm{mg}, 81 \%, \mathrm{mp} 166-168{ }^{\circ} \mathrm{C} .{ }^{1} \mathrm{H} \mathrm{NMR} \delta \mathrm{ppm}: 3.86\left(3 \mathrm{H}, \mathrm{s}, \mathrm{CH}_{3}\right), 7.68(2 \mathrm{H}, \mathrm{t}, \mathrm{J}=7.6 \mathrm{~Hz}$, 
Ph-H), $7.78(1 \mathrm{H}, \mathrm{t}, J=7.6 \mathrm{~Hz}, \mathrm{Ph}-\mathrm{H}), 8.03\left(2 \mathrm{H}, \mathrm{s}, \mathrm{SO}_{2} \mathrm{NH}_{2}\right), 8.07(2 \mathrm{H}, \mathrm{d}, J=7.6 \mathrm{~Hz}, \mathrm{Ph}-\mathrm{H})$, $8.23\left(1 \mathrm{H}, \mathrm{s}, \mathrm{C}_{3}-\mathrm{H}\right), 8.51\left(1 \mathrm{H}, \mathrm{s}, \mathrm{C}_{6}-\mathrm{H}\right) .{ }^{13} \mathrm{C}$ NMR $\delta$ ppm: 53.8, 128.5, 130.1, 130.3, 131.7, 133.5, $134.2,134.9,140.0,142.3,146.0,165.7$. HRMS calculated for $\mathrm{C}_{14} \mathrm{H}_{12} \mathrm{ClNO}_{6} \mathrm{~S}_{2}\left[(\mathrm{M}+\mathrm{H})^{+}\right]$: 389.9867, found: 389.9869 .

Methyl 4-chloro-2-cyclohexylsulfonyl-5-sulfamoyl-benzoate (9b, EA1-3No). Yield: $150 \mathrm{mg}$, 76\%, mp 181-183 ${ }^{\circ} \mathrm{C} .{ }^{1} \mathrm{H}$ NMR $\delta$ ppm: 1.18-1.30 (3H, m, Cy-H), 1.41-1.50 (2H, m, Cy-H), 1.62-1.66 (1H, m, Cy-H), 1.80-1.91 (4H, m, Cy-H), 3.64-3.70 (1H, m, Cy-H), 3.90 (3H, s, $\left.\mathrm{CH}_{3}\right), 8.06\left(2 \mathrm{H}, \mathrm{s}, \mathrm{SO}_{2} \mathrm{NH}_{2}\right), 8.12\left(1 \mathrm{H}, \mathrm{s}, \mathrm{C}_{3}-\mathrm{H}\right), 8.30\left(1 \mathrm{H}, \mathrm{s}, \mathrm{C}_{6}-\mathrm{H}\right) .{ }^{13} \mathrm{C}$ NMR $\delta$ ppm: 24.8 , $25.0,25.1,54.0,62.9,130.5,132.6,133.8,134.1,140.1,145.9,165.9$. HRMS calculated for $\mathrm{C}_{14} \mathrm{H}_{18} \mathrm{ClNO}_{6} \mathrm{~S}_{2}\left[(\mathrm{M}+\mathrm{H})^{+}\right]: 396.0337$, found: 396.0341 .

Methyl 2-benzylsulfonyl-4-chloro-5-sulfamoylbenzoate (9c, EA1-4No). Yield: $162 \mathrm{mg}, 80 \%$, mp 224-225 ${ }^{\circ} \mathrm{C} .{ }^{1} \mathrm{H}$ NMR $\delta$ ppm: $3.97\left(3 \mathrm{H}, \mathrm{s}, \mathrm{CH}_{3}\right), 4.97\left(2 \mathrm{H}, \mathrm{s}, \mathrm{CH}_{2}\right), 7.27-7.30(2 \mathrm{H}, \mathrm{m}$, $\mathrm{Ph}-\mathrm{H}), 7.37-7.42(3 \mathrm{H}, \mathrm{m}, \mathrm{Ph}-\mathrm{H}), 7.79\left(1 \mathrm{H}, \mathrm{s}, \mathrm{C}_{3}-\mathrm{H}\right), 8.07\left(2 \mathrm{H}, \mathrm{s}, \mathrm{SO}_{2} \mathrm{NH}_{2}\right), 8.31\left(1 \mathrm{H}, \mathrm{s}, \mathrm{C}_{6}-\mathrm{H}\right)$. ${ }^{13}$ C NMR $\delta$ ppm: 54.2, 61.7, 127.7, 129.1, 129.4, 130.4, 131.7, 132.1, 133.6, 133.9, 140.9, 145.9, 166.0. HRMS calculated for $\mathrm{C}_{15} \mathrm{H}_{14} \mathrm{ClNO}_{6} \mathrm{~S}_{2}\left[(\mathrm{M}+\mathrm{H})^{+}\right]$: 404.0024, found: 404.0018 .

Methyl 4-chloro-2-(2-phenylethylsulfonyl)-5-sulfamoylbenzoate (9d, EA1-5o). Recrystallization was accomplished from MeOH. Yield: $142 \mathrm{mg}, 68 \%, \mathrm{mp} 156-158{ }^{\circ} \mathrm{C}$. ${ }^{1} \mathrm{H}$ NMR $\delta \mathrm{ppm}$ : $3.06\left(2 \mathrm{H}, \mathrm{t}, J=7.6 \mathrm{~Hz}, \mathrm{CH}_{2}\right), 3.91\left(3 \mathrm{H}, \mathrm{s}, \mathrm{CH}_{3}\right), 4.00\left(2 \mathrm{H}, \mathrm{t}, J=8.0 \mathrm{~Hz}, \mathrm{CH}_{2}\right), 7.16-7.20(1 \mathrm{H}, \mathrm{m}$, Ph-H) 7.21-7.27 (4H, m, Ph-H), $8.03\left(1 \mathrm{H}, \mathrm{s}, \mathrm{C}_{3}-\mathrm{H}\right), 8.04\left(2 \mathrm{H}, \mathrm{s}, \mathrm{SO}_{2} \mathrm{NH}_{2}\right), 8.26\left(1 \mathrm{H}, \mathrm{s}, \mathrm{C}_{6}-\mathrm{H}\right)$. ${ }^{13} \mathrm{C}$ NMR $\delta$ ppm: 28.2, 54.1, 56.5, 127.2, 128.89, 128.92, 130.3, 131.8, 133.8, 133.9, 137.8, 141.5, 145.8, 165.9. HRMS calculated for $\mathrm{C}_{16} \mathrm{H}_{16} \mathrm{ClNO}_{6} \mathrm{~S}_{2}\left[(\mathrm{M}+\mathrm{H})^{+}\right]$: 418.0180 , found: 418.0178 .

Methyl 4-chloro-2-(1-naphthylsulfonyl)-5-sulfamoylbenzoate (9f, EA2-NFo). Yield: $180 \mathrm{mg}$, $82 \%$, mp 244-245 ${ }^{\circ} \mathrm{C} .{ }^{1} \mathrm{H}$ NMR $\delta$ ppm: 3.72 (3H, s, $\left.\mathrm{CH}_{3}\right), 7.66-7.75(2 \mathrm{H}, \mathrm{m}, \mathrm{Naph}-\mathrm{H}), 7.81$ $(1 \mathrm{H}, \mathrm{t}, J=7.6 \mathrm{~Hz}, \mathrm{Naph}-\mathrm{H}), 8.00\left(2 \mathrm{H}, \mathrm{s}, \mathrm{SO}_{2} \mathrm{NH}_{2}\right), 8.17(1 \mathrm{H}, \mathrm{d}, J=8.0 \mathrm{~Hz}, \mathrm{Naph}-\mathrm{H}), 8.23$ $\left(1 \mathrm{H}, \mathrm{s}, \mathrm{C}_{3}-\mathrm{H}\right), 8.35\left(1 \mathrm{H}, \mathrm{s}, \mathrm{C}_{6}-\mathrm{H}\right), 8.36(2 \mathrm{H}, \mathrm{t}, J=8.0 \mathrm{~Hz}, \mathrm{Naph}-\mathrm{H}), 8.41(1 \mathrm{H}, \mathrm{d}, J=8.4 \mathrm{~Hz}$, Naph-H). ${ }^{13}$ C NMR $\delta$ ppm: 53.8, 123.5, 125.2, 127.7, 127.8, 129.5, 130.1, 130.6, 131.5, 131.6, $132.4,133.9,134.0,134.2,136.4,142.4,145.8,165.4$. HRMS calculated for $\mathrm{C}_{18} \mathrm{H}_{14} \mathrm{ClNO}_{6} \mathrm{~S}_{2}$ $\left[(\mathrm{M}+\mathrm{H})^{+}\right]:$440.0024,found: 440.0020 .

Methyl 2-(benzenesulfonyl)-4-bromo-5-sulfamoylbenzoate (10a, LJ15-11o). Yield: 189 mg, 87\%, mp 191-193 ${ }^{\circ} \mathrm{C} .{ }^{1} \mathrm{H}$ NMR $\delta$ ppm: $3.86\left(3 \mathrm{H}, \mathrm{s}, \mathrm{CH}_{3}\right), 7.67-7.79(3 \mathrm{H}, \mathrm{m}, \mathrm{Ph}-\mathrm{H}), 7.98(2 \mathrm{H}$, $\left.\mathrm{s}, \mathrm{SO}_{2} \mathrm{NH}_{2}\right), 8.04-8.07(2 \mathrm{H}, \mathrm{m}, \mathrm{Ph}-\mathrm{H}), 8.22\left(1 \mathrm{H}, \mathrm{s}, \mathrm{C}_{6}-\mathrm{H}\right), 8.62\left(1 \mathrm{H}, \mathrm{s}, \mathrm{C}_{3}-\mathrm{H}\right) .{ }^{13} \mathrm{C}$ NMR $\delta$ ppm: $53.8,122.7,128.5,130.1,130.2,132.2,134.9,136.7,140.0,141.9,147.8,165.8$. HRMS calculated for $\mathrm{C}_{14} \mathrm{H}_{12} \mathrm{BrNO}_{6} \mathrm{~S}_{2}\left[(\mathrm{M}+\mathrm{H})^{+}\right]$: 435.9342 (100\%), found: 435.9345 (100\%).

\subsection{General Procedure for the Syntheses of $\mathbf{1 2} \mathbf{a}-\mathbf{d}, \mathbf{f}$}

The mixture of methyl 2,4-dichloro-5-sulfamoylbenzamide (11) [8] (269 mg, $1.00 \mathrm{mmol}$, DMSO (1.5 mL), appropriate thiol $(1.10 \mathrm{mmol})$, and TEA $(121 \mathrm{mg}, 1.20 \mathrm{mmol})$ was heated at $60{ }^{\circ} \mathrm{C}$ temperature for $12 \mathrm{~h}$. The mixture was cooled to room temperature, and brine $(15 \mathrm{~mL})$ was added. The product was extracted with EtOAc $(3 \times 15 \mathrm{~mL})$. The organic layer was washed with $\mathrm{H}_{2} \mathrm{O}$, dried over anhydrous $\mathrm{MgSO}_{4}$, filtered, and concentrated.

4-chloro-2-(1-naphthylsulfanyl)-5-sulfamoylbenzamide (12f, EA1A-NF). The product was crystallized from toluene:MeOH (7:1).Yield: $277 \mathrm{mg}, 70 \%, \mathrm{mp} 277-280{ }^{\circ} \mathrm{C} .{ }^{1} \mathrm{H} \mathrm{NMR} \delta \mathrm{ppm}$ : $6.38\left(1 \mathrm{H}, \mathrm{s}, \mathrm{C}_{3}-\mathrm{H}\right), 7.59\left(2 \mathrm{H}, \mathrm{s}, \mathrm{SO}_{2} \mathrm{NH}_{2}\right), 7.61-7.66(2 \mathrm{H}, \mathrm{m}, \mathrm{Naph}-\mathrm{H}), 7.67-7.71(1 \mathrm{H}, \mathrm{m}$, Naph-H), $7.85\left(1 \mathrm{H}, \mathrm{s}, \mathrm{CONH}_{2}\right), 8.00(1 \mathrm{H}, \mathrm{dd}, J=7.2 \mathrm{~Hz}, J=1.2 \mathrm{~Hz}, \mathrm{Naph}-\mathrm{H}), 8.10(1 \mathrm{H}, \mathrm{s}$, $\left.\mathrm{C}_{6}-\mathrm{H}\right), 8.10-8.14$ (2H, m, Naph-H), $8.21(1 \mathrm{H}, \mathrm{d}, J=8.4 \mathrm{~Hz}, \mathrm{Naph}-\mathrm{H}), 8.34\left(1 \mathrm{H}, \mathrm{s}, \mathrm{CONH}_{2}\right)$. ${ }^{13}$ C NMR $\delta$ ppm: 125.2, 127.0, 127.5, 127.7, 128.5 128.6, 128.9, 129.7, 131.1, 132.1, 132.3, 133.7, 134.6, 135.0, 136.6, 137.5, 168.0. HRMS calculated for $\mathrm{C}_{17} \mathrm{H}_{13} \mathrm{ClN}_{2} \mathrm{O}_{3} \mathrm{~S}_{2}\left[(\mathrm{M}+\mathrm{H})^{+}\right]: 393.0129$, found: 393.0133 .

4-chloro-2-phenylsulfanyl-5-sulfamoylbenzamide (12a, EA1A-2) [9].

4-chloro-2-cyclohexylsulfanyl-5-sulfamoylbenzamide (12b, EA1A-3) [9].

2-benzylsulfanyl-4-chloro-5-sulfamoylbenzamide (12c, EA1A-4) [9].

4-chloro-2-(2-phenylethylsulfanyl)-5-sulfamoylbenzamide (12d, EA1A-5) [9]. 


\subsection{General Procedure for the Syntheses of $\mathbf{5 a}-\mathbf{d}, \mathbf{f}$}

The mixture of appropriate 2-substituted 4-chloro-5-sulfamoylbenzamide (compounds 12a-d,f) $(0.500 \mathrm{mmol})$, methanol $(5 \mathrm{~mL})$, and thionyl chloride $(0.200 \mathrm{~mL}, 2.76 \mathrm{mmol})$ was heated at $50{ }^{\circ} \mathrm{C}$ temperature for $48-96 \mathrm{~h}$. The progress of the reaction was monitored by TLC. The mixture was concentrated under reduced pressure.

Methyl 4-chloro-2-phenylsulfanyl-5-sulfamoylbenzoate (5a, EA2-2). The product was recrystallized from $\mathrm{H}_{2} \mathrm{O}$. Yield: $122 \mathrm{mg}, 68 \%, \mathrm{mp} 223-226{ }^{\circ} \mathrm{C}$.

Methyl 4-chloro-2-cyclohexylsulfanyl-5-sulfamoylbenzoate (5b, EA1-3N). The product was recrystallized from $\mathrm{H}_{2} \mathrm{O}$. Yield: $120 \mathrm{mg}, 66 \%$, mp 150-151 ${ }^{\circ} \mathrm{C} .{ }^{1} \mathrm{H}$ NMR $\delta$ ppm: $1.20-1.51$ (5H, m, Cy-H), 1.58-1.66 (1H, m, Cy-H), 1.69-1.77 (2H, m, Cy-H), 1.93-2.02 (2H, m, Cy-H), 3.60-3.69 (1H, m, Cy-H), $3.86\left(3 \mathrm{H}, \mathrm{s}, \mathrm{CH}_{3}\right), 7,65\left(1 \mathrm{H}, \mathrm{s}, \mathrm{C}_{3}-\mathrm{H}\right), 7.71\left(2 \mathrm{H}, \mathrm{s}, \mathrm{SO}_{2} \mathrm{NH}_{2}\right), 8.39$ $\left(1 \mathrm{H}, \mathrm{s}, \mathrm{C}_{6}-\mathrm{H}\right) .{ }^{13} \mathrm{C}$ NMR $\delta$ ppm: 25.6, 25.7, 32.5, 42.9, 53.1, 126.3, 129.0, 131.6, 135.0, 136.9, 146.9, 165.0. HRMS calculated for $\mathrm{C}_{14} \mathrm{H}_{18} \mathrm{ClNO}_{4} \mathrm{~S}_{2}\left[(\mathrm{M}+\mathrm{H})^{+}\right]$: 364.0439 , found: 364.0444 .

Methyl 2-benzylsulfanyl-4-chloro-5-sulfamoylbenzoate (5c, EA1-4N). The product was recrystallized from $\mathrm{H}_{2} \mathrm{O}$. Yield: $145 \mathrm{mg}, 78 \%, \mathrm{mp} 211-212{ }^{\circ} \mathrm{C} .{ }^{1} \mathrm{H}$ NMR $\delta \mathrm{ppm}: 3.86(3 \mathrm{H}, \mathrm{s}$, $\left.\mathrm{CH}_{3}\right), 4.42\left(2 \mathrm{H}, \mathrm{s}, \mathrm{CH}_{2}\right), 7.30(1 \mathrm{H}, \mathrm{t}, J=7.2 \mathrm{~Hz}, \mathrm{Ph}-\mathrm{H}), 7.37(2 \mathrm{H}, \mathrm{t}, J=7.2 \mathrm{~Hz}, \mathrm{Ph}-\mathrm{H}), 7.47$ $(2 \mathrm{H}, \mathrm{d}, J=6.8 \mathrm{~Hz}, \mathrm{Ph}-\mathrm{H}) 7.70\left(1 \mathrm{H}, \mathrm{s}, \mathrm{C}_{3}-\mathrm{H}\right), 7.73\left(2 \mathrm{H}, \mathrm{s}, \mathrm{SO}_{2} \mathrm{NH}_{2}\right), 8.44\left(1 \mathrm{H}, \mathrm{s}, \mathrm{C}_{6}-\mathrm{H}\right) .{ }^{13} \mathrm{C}$ NMR $\delta$ ppm: 36.0, 53.1, 124.7, 128.0, 128.5, 129.1, 129.7, 131.6, 135.2, 136.0, 136.8, 148.4, 164.9. HRMS calculated for $\mathrm{C}_{15} \mathrm{H}_{14} \mathrm{ClNO}_{4} \mathrm{~S}_{2}\left[(\mathrm{M}+\mathrm{H})^{+}\right]$: 372.0126, found: 372.0129 .

Methyl 4-chloro-2-(2-phenylethylsulfanyl)-5-sulfamoylbenzoate (5d, EA1-5N). The product was recrystallized from $\mathrm{H}_{2} \mathrm{O}$ :acetone (3:1). Yield: $166 \mathrm{mg}, 85 \%, \mathrm{mp} 135-137{ }^{\circ} \mathrm{C}$. ${ }^{1} \mathrm{H}$ NMR

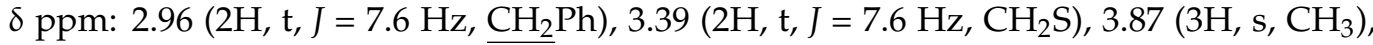
$7.24(1 \mathrm{H}, \mathrm{m}, \mathrm{Ph}-\mathrm{H}), 7.29-7.33(4 \overline{\mathrm{H}}, \mathrm{m}, \mathrm{Ph}-\mathrm{H}), 7.63\left(1 \mathrm{H}, \mathrm{s}, \mathrm{C}_{3}-\mathrm{H}\right), 7.73\left(2 \mathrm{H}, \mathrm{s}, \mathrm{SO}_{2} \mathrm{NH}_{2}\right), 8.44$ $\left(1 \mathrm{H}, \mathrm{s}, \mathrm{C}_{6}-\mathrm{H}\right) .{ }^{13} \mathrm{C}$ NMR $\delta$ ppm: 33.7, 33.8, 53.1, 125.1, 126.9, 128.3, 128.9, 129.0, 131.6, 135.3, 136.7, 140.1, 148.5, 164.9. HRMS calculated for $\mathrm{C}_{16} \mathrm{H}_{16} \mathrm{ClNO}_{4} \mathrm{~S}_{2}\left[(\mathrm{M}+\mathrm{H})^{+}\right]$: 386.0282 , found: 386.0286 .

Methyl 4-chloro-2-(1-naphthylsulfanyl)-5-sulfamoylbenzoate (5f, EA2-NF). The product was recrystallized from $\mathrm{H}_{2} \mathrm{O}: \mathrm{MeOH}(4: 1)$. Yield: $143 \mathrm{mg}, 70 \%, \mathrm{mp} 235-237{ }^{\circ} \mathrm{C}$.

\subsection{Protein Preparation}

Recombinant human carbonic anhydrases (CAs) were expressed in E. coli (CAI, CAII, mutant CAII A65S, N67Q, 191L, F130V, V134L, L203A, CAIII, CAIV, CAVA, CAVB, CAVII, CAXII, CAXIII, CAXIV), yeast (CAIX used to obtain only PDB ID: 7POM crystal structure) or mammalian cells (CAVI and CAIX used for all remaining experiments). Proteins were chromatographically purified following published protocols: CAI [22], CAII [23],

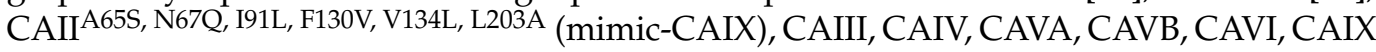
(except CAIX (PDB ID: 7POM) crystal was obtained using yeast-expressed protein [24], and [17], CAVII, CAXIII- [25], CAXII [26]. The protein stock solutions were stored at $-80{ }^{\circ} \mathrm{C}$. The protein concentration was determined by UV absorption at $280 \mathrm{~nm}$ using BeerLambert law and extinction coefficient determined by amino acid analysis. Proteins used for crystallization were additionally purified by affinity chromatography and concentrated.

\subsection{Determination of Binding Parameters}

\subsubsection{Fluorescent Thermal Shift Assay (FTSA)}

Observed affinities (dissociation constant, $K_{d, o b s}$, proportional to the change in standard Gibbs energy upon binding, $\Delta G=R T \ln K_{d}$ ) of the compounds binding to CAs were determined by the fluorescent thermal shift assay $[27,28]$, using a QIAGEN's real-time PCR cycler the "Rotor-Gene $Q^{\prime \prime}$ and Rotor-Gene ${ }^{\circledR}$ Style 4-strip tubes from STARLAB. Ligands were dissolved in DMSO stock solutions to concentrations of $10 \mathrm{mM}$ or $20 \mathrm{mM}$ and used for the serial dilution in DMSO of the dilution factor 2. These samples were diluted with buffer solution and mixed with a prepared protein solution, consisting of protein stock, buffer solution, and 8-anilino-1-naphthalene sulfonate (ANS; solvatochromic dye). All final samples typically contained up to $10 \mu \mathrm{M} \mathrm{CA}$, compound solutions of serial dilution from $0 \mu \mathrm{M}$ to $200 \mu \mathrm{M}$ at 8 different concentrations differing by two times, $50 \mu \mathrm{M}$ ANS, 
$50 \mathrm{mM}$ sodium phosphate buffer at pH 7.0, $100 \mathrm{mM}$ sodium chloride, and 2.0\% (v/v) DMSO. Samples preparation is explained in detail in [28]. Protein denaturation was monitored by determining the fluorescence of ANS as a function of temperature[29]. The excitation and emission wavelengths of ANS are $365 \pm 20$ and $460 \pm 15 \mathrm{~nm}$. Samples were heated from $25{ }^{\circ} \mathrm{C}$ to $99{ }^{\circ} \mathrm{C}$ at the rate of $1^{\circ} \mathrm{C} / \mathrm{min}$. The curve-fitting procedure has been explained previously [30] and was performed at $37^{\circ} \mathrm{C}$.

The dissociation constants of each compound with all 12 catalytically active human CAs are listed in Table 2, and some experimental data are provided in Supplementary material in Figures S1 and S2.

\subsubsection{Isothermal Titration Calorimetry (ITC)}

Additionally, a selected set of compounds binding to CAs were tested by ITC [31,32] to determine changes in binding enthalpies. ITC experiments were carried out using a MicroCal PEAQ-ITC calorimeter (Northampton, MA, USA). The protein solution in the cell contained a constant concentration of CA (10-20 $\mu \mathrm{M})$, while the concentration of compound loaded in the ITC syringe was ten times higher than the protein concentration $(100-200 \mu \mathrm{M})$. Both cell and syringe solutions were diluted in the buffer: $50 \mathrm{mM}$ sodium phosphate at pH 7.0 and containing $100 \mathrm{mM}$ sodium chloride and $2.0 \%(v / v)$ of DMSO. Samples were centrifuged prior to the experiment to improve quality. A typical experiment consisted of 19 injections with $150 \mathrm{~s}$ spacing between injections; the volume of the first injection was $0.4 \mu \mathrm{L}$ (duration $0.8 \mathrm{~s}$ ) and $2.0 \mu \mathrm{L}$ (duration $4.0 \mathrm{~s}$ ) for the remaining injections. All experiments were performed at $37^{\circ} \mathrm{C}$ with reference power $4.0 \mu \mathrm{cal} / \mathrm{s}$.

The enthalpy changes of binding are listed in Table S8, and experimental data are provided in Supplementary material in Figure S6. A comparison of the affinity determined by FTSA and ITC is shown in Supplementary material in Figure S9. ITC shows weaker affinity than FTSA for strong interactions. Thus, the affinity determined by the FTSA was used due to the ITC detection limit as the more reliable.

\subsubsection{Calculation of Intrinsic Binding Parameters}

All experiments allow the determination of the observed binding parameters of the sulfonamide binding to CA. However, the change in standard Gibbs energy (or dissociation constant), enthalpy, and entropy upon binding depend on buffer and $\mathrm{pH}$ because sulfonamide binding to CAs is linked to several reactions: (i) $\mathrm{Zn}^{2+}$-bound hydroxide ion protonate into water molecule in the active site of CA; (ii) Sulfonamide amino group $\left(\mathrm{R}-\mathrm{SO}_{2} \mathrm{NH}_{2}\right)$ deprotonate $\left(\mathrm{R}-\mathrm{SO}_{2} \mathrm{NH}^{-}\right)$; (iii) Buffer molecule protonate or deprotonate depending on the protons' balance; (iv) After these reactions, the negatively charged sulfonamide $\left(\mathrm{R}-\mathrm{SO}_{2} \mathrm{NH}^{-}\right)$ replaces the $\mathrm{Zn}^{2+}$-bound water molecule in the active site of CA and binds to the protein in its position [15]. The sum of these reactions is the observed binding. However, only the fourth reaction represents the actual binding reaction, called intrinsic [16]. Observed binding parameters are important to obtain the compound's affinity under certain conditions, for example, in the human body. Nevertheless, these parameters are less important in the drug design to estimate the energy for the binding affinity of each substituent. However, the contribution of protonation reactions can be subtracted. Equations of intrinsic dissociation constant $\left(K_{d_{-} \text {intr }}\right)$ or standard Gibbs energy $\left(\Delta G_{\text {intr }}\right)$ and enthalpy change $\left(\Delta H_{\text {intr }}\right)$ are listed in Table 2 and Table S7 in Supplementary materials.

\subsection{Determination of Protonation Parameters}

\subsubsection{Determination of $\mathrm{pK}_{a}$ Values}

The $\mathrm{p} K_{a}$ values of water molecules bound to $\mathrm{Zn}^{2+}$ in the active site of CAs, $\mathrm{p} K_{a \_C A Z n(I I) H 2 O}$, were taken from [33] and of compounds, $\mathrm{p} K_{a_{-} R S O 2 N H 2}$, were determined as described in [34]. Figure 2D shows the intrinsic parameters of the binding of mimic-CAIX (mutant

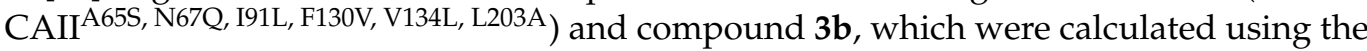
$\mathrm{p} K_{a_{-} C A Z n(I I) H 2 O}$ of CAII. 
We used a constant concentration of sulfonamide $(25-400 \mu \mathrm{M})$ and $2.0 \%(v / v)$ of DMSO in universal buffer ( $50 \mathrm{mM}$ sodium acetate, $25 \mathrm{mM}$ sodium borate, and $50 \mathrm{mM}$ sodium phosphate) at different $\mathrm{pH}$ values (in the range from $\mathrm{pH} 6$ to 12 at every half $\mathrm{pH}$ unit). UV-VIS spectra of compound solution were recorded at $37^{\circ} \mathrm{C}$ using the spectrophotometer "Agilent $89090 \mathrm{~A}^{\prime}$. To determine $\mathrm{p} K_{a_{-} R S O 2 N H 2}$, a plot of the normalized ratio of two absorbancies (approximately $10 \mathrm{~nm}$ above and $10 \mathrm{~nm}$ below the isosbestic point) vs. buffer $\mathrm{pH}$ and fitted Henderson-Hasselbach curve using the least-square method. The midpoint of this fitted curve is equal to $\mathrm{pK}_{a_{-} \mathrm{RSO} N \mathrm{NH} 2}$. Experimental data are provided in Supplementary material in Figure S5 and Table 2.

\subsubsection{Determination of Protonation Enthalpy}

The enthalpy changes of sulfonamide amino group $\left(\mathrm{RSO}_{2} \mathrm{NH}_{2}\right)$ protonation, $\Delta_{p \_R S O} \mathrm{NH}_{2} H$, were determined by titration of $0.25 \mathrm{mM}$ sulfonamide and $0.375 \mathrm{mM}$ sodium hydroxide with $2.75 \mathrm{mM}$ nitric acid using a MicroCal PEAQ-ITC calorimeter (Northampton, MA, USA). DMSO concentrations in the syringe and the sample cell were $2 \%(v / v)$. Experimental parameters: total number of injections was 40 , the volume of each injection was $0.9 \mu \mathrm{L}$, spacing between injections was $120 \mathrm{~s}$, the temperature was $37^{\circ} \mathrm{C} . \Delta_{p_{-}} \mathrm{CAZn}(\mathrm{II}) \mathrm{H} 2 \mathrm{O} H$ values of the water molecule in the active site CAs were taken from [33]. Figure 2D shows the change in binding enthalpy of mimic-CAIX (mutant CAII ${ }^{\mathrm{A} 65 \mathrm{~S},}$ N67Q, I91L, F130V, V134L, L203A) and compound $\mathbf{3 b}$, which was calculated using the $\Delta_{p_{-} C A Z n(I) H 2 O} H$ of CAII. Experimental data are provided in Supplementary material in Figure S7 and Table S5.

\subsection{X-ray Crystallography: Crystallization, Data Collection, and Structure Determination}

The proteins were ultrafiltered to the indicated concentration in Table S4. The same table lists the crystallization conditions and solutions. Crystals of CAIX (PDB ID: 7POM) and CAXII (PDB ID: 7PP9) were achieved by co-crystallization and others by soaking. The crystal soaking ligand solutions were produced by combining $50 \mu \mathrm{L}$ of matching reservoir solution with $1 \mu \mathrm{L}$ of $50 \mathrm{mM}$ ligand solution in DMSO. The data were processed and scaled using XDS [35], MOSFLM [36], and SCALA [37]. Except CAXII dataset was processed and scaled using SAINT [38] and SADABS [39]. MOLREP [40] was used for molecular replacement with an initial model of 1 CAB for CAI, 4HT0 for CAII, 3HLJ for mimic-CAIX, 6FE2 for CAIX, and 6QNL for CAXII. The model was refined with REFMAC [41] and fitted in the electron density map using COOT [42]. The 3D models of compounds were constructed by AVOGADRO [43] program, and ligand parameter files were created using LIBCHECK $[44,45]$. Coordinates and structure factors have been deposited to PDB. The PDB IDs, data collection, and refinement statistics are shown in Supplementary material in Table S3. The PyMOL program was used to create graphics.

Supplementary Materials: The following are available online at https:/ /www.mdpi.com/article/10 $.3390 /$ ijms23010130/s1.

Author Contributions: Conceptualization, A.Z. and E.Č.; methodology, A.Z. and E.Č.; investigation, A.Z., V.P.-L., A.S. (Alexey Smirnov), J.L., A.K., E.D., L.S., A.M., J.J., L.J., V.L., A.S. (Andrius Sakalauskas) and J.M.; resources, E.M. and S.G.; writing-original draft preparation, V.P.-L.; writingreview and editing, A.Z.; supervision, K.T., D.M.; project administration, D.M.; funding acquisition, J.L., J.M. and D.M. All authors have read and agreed to the published version of the manuscript.

Funding: This work was supported by the grant S-SEN-20-10 from the Research Council of Lithuania. J.L. was supported by the European Regional Development Fund (ERDF) grant No. 1.1.1.2/VIAA/3/19/464 'Structural and kinetic studies of human carbonic anhydrases as multiple drug targets'. Access to EMBL beamlines was in part supported by the European Community's Seventh Framework Programme (FP7/2007-2013) under grant agreement number 283570 and by iNEXT funded by the Horizon 2020 program of the European Commission [grant number 653706].

Data Availability Statement: The data that support the findings of this study are available from the corresponding author upon reasonable request. 
Conflicts of Interest: The authors declare that they may have authored patent applications on carbonic anhydrase inhibitors.

$\begin{array}{ll}\text { Abbreviations } \\ \text { CA } & \text { carbonic anhydrase } \\ \text { FTSA } & \text { fluorescent thermal shift assay (or differential scanning fluorimetry, DSF) } \\ \text { intr } & \text { intrinsic } \\ \text { ITC } & \text { isothermal titration calorimetry } \\ \text { obs } & \text { observed } \\ \text { VARIABLES } & \\ \Delta G_{\text {intr }} & \text { change of the intrinsic standard Gibbs energy upon binding } \\ \Delta G_{o b s} & \text { change of the observed standard Gibbs energy upon binding } \\ \Delta H_{\text {intr }} & \text { change of the intrinsic standard enthalpy upon binding } \\ \Delta H_{\text {obs }} & \text { change of the observed standard enthalpy upon binding } \\ K_{d \_i n t r} & \text { the intrinsic equilibrium dissociation constant } \\ K_{d \_o b s} & \text { the observed equilibrium dissociation constant } \\ T_{m} & \text { melting temperature (midpoint of the unfolding transition) } \\ T \Delta S_{\text {intr }} & \text { change of the intrinsic standard entropy upon binding multiplied by absolute } \\ & \text { temperature }\end{array}$

\section{References}

1. Dodgson, S.J.; Tashian, R.E.; Gros, G.; Carter, N.D. (Eds.) The Carbonic Anhydrases; Springer: Boston, MA, USA, 1991.

2. Chegwidden, W.R.; Carter, N.D.; Edwards, Y.H. (Eds.) The Carbonic Anhydrases; Birkhäuser: Basel, Switzerland, 2000.

3. Oosterwijk, E.; Ruiter, D.J.; Hoedemaeker, P.J.; Pauwels, E.K.; Jonas, U.; Zwartendijk, J.; Warnaar, S.O. Monoclonal antibody G 250 recognizes a determinant present in renal-cell carcinoma and absent from normal kidney. Int. J. Cancer 1986, 38, 489-494. [CrossRef] [PubMed]

4. Pastorek, J.; Pastoreková, S.; Callebaut, I.; Mornon, J.P.; Zelník, V.; Opavský, R.; Zat'ovicová, M.; Liao, S.; Portetelle, D.; Stanbridge, E.J. Cloning and characterization of $\mathrm{MN}$, a human tumor-associated protein with a domain homologous to carbonic anhydrase and a putative helix-loop-helix DNA binding segment. Oncogene 1994, 9, 2877-2888.

5. Saarnio, J.; Parkkila, S.; Parkkila, A.-K.; Haukipuro, K.; Pastoreková, S.; Pastorek, J.; Kairaluoma, M.I.; Karttunen, T.J. Immunohistochemical Study of Colorectal Tumors for Expression of a Novel Transmembrane Carbonic Anhydrase, MN/CA IX, with Potential Value as a Marker of Cell Proliferation. Am. J. Pathol. 1998, 153, 279-285. [CrossRef]

6. Krishnamurthy, V.M.; Kaufman, G.K.; Urbach, A.R.; Gitlin, I.; Gudiksen, K.L.; Weibel, D.B.; Whitesides, G.M. Carbonic Anhydrase as a Model for Biophysical and Physical-Organic Studies of Proteins and Protein-Ligand Binding. Chem. Rev. 2008, 108, 946-1051. [CrossRef]

7. Lomelino, C.L.; Andring, J.T.; McKenna, R. Crystallography and Its Impact on Carbonic Anhydrase Research. Int. J. Med. Chem. 2018, 2018, 9419521. [CrossRef] [PubMed]

8. Zakšauskas, A.; Čapkauskaitè, E.; Jezepčikas, L.; Linkuvienė, V.; Kišonaitè, M.; Smirnov, A.; Manakova, E.; Gražulis, S.; Matulis, D. Design of two-tail compounds with rotationally fixed benzenesulfonamide ring as inhibitors of carbonic anhydrases. Eur. J. Med. Chem. 2018, 156, 61-78. [CrossRef]

9. Zakšauskas, A.; Čapkauskaitè, E.; Jezepčikas, L.; Linkuvienė, V.; Paketurytė, V.; Smirnov, A.; Leitans, J.; Kazaks, A.; Dvinskis, E.; Manakova, E.; et al. Halogenated and di-substituted benzenesulfonamides as selective inhibitors of carbonic anhydrase isoforms. Eur. J. Med. Chem. 2020, 185, 111825. [CrossRef]

10. Dudutienè, V.; Zubrienè, A.; Kairys, V.; Smirnov, A.; Smirnovienè, J.; Leitans, J.; Kazaks, A.; Tars, K.; Manakova, L.; Gražulis, S.; et al. Isoform-Selective Enzyme Inhibitors by Exploring Pocket Size According to the Lock-and-Key Principle. Biophys. J. 2020, 119, 1513-1524. [CrossRef]

11. Scott, A.D.; Phillips, C.; Alex, A.; Flocco, M.; Bent, A.; Randall, A.; O’Brien, R.; Damian, L.; Jones, L.H. Thermodynamic Optimisation in Drug Discovery: A Case Study using Carbonic Anhydrase Inhibitors. ChemMedChem 2009, 4, 1985-1989. [CrossRef]

12. Čapkauskaitè, E.; Zubrienè, A.; Baranauskienė, L.; Tamulaitienè, G.; Manakova, E.; Kairys, V.; Gražulis, S.; Tumkevičius, S.; Matulis, D. Design of [(2-pyrimidinylthio)acetyl]benzenesulfonamides as inhibitors of human carbonic anhydrases. Eur. J. Med. Chem. 2012, 51, 259-270. [CrossRef] [PubMed]

13. Čapkauskaitè, E.; Zubrienè, A.; Smirnov, A.; Torresan, J.; Kišonaitė, M.; Kazokaitė, J.; Gylytė, J.; Michailovienė, V.; Jogaitė, V.; Manakova, E.; et al. Benzenesulfonamides with pyrimidine moiety as inhibitors of human carbonic anhydrases I, II, VI, VII, XII, and XIII. Bioorg. Med. Chem. 2013, 21, 6937-6947. [CrossRef]

14. Singh, S.; Lomelino, C.; Mboge, M.; Frost, S.; McKenna, R. Cancer Drug Development of Carbonic Anhydrase Inhibitors beyond the Active Site. Molecules 2018, 23, 1045. [CrossRef] [PubMed] 
15. Fisher, S.Z.; Aggarwal, M.; Kovalevsky, A.Y.; Silverman, D.N.; McKenna, R. Neutron Diffraction of Acetazolamide-Bound Human Carbonic Anhydrase II Reveals Atomic Details of Drug Binding. J. Am. Chem. Soc. 2012, 134, 14726-14729. [CrossRef] [PubMed]

16. Zubrienè, A.; Matulis, D. Observed Versus Intrinsic Thermodynamics of Inhibitor Binding to Carbonic Anhydrases. In Carbonic Anhydrase as Drug Target: Thermodynamics and Structure of Inhibitor Binding; Matulis, D., Ed.; Springer International Publishing: Cham, Switzerland, 2019; pp. 107-123.

17. Dudutienè, V.; Matulienè, J.; Smirnov, A.; Timm, D.D.; Zubrienè, A.; Baranauskienė, L.; Morkūnaite, V.; Smirnovienė, J.; Michailovienè, V.; Juozapaitienè, V.; et al. Discovery and characterization of novel selective inhibitors of carbonic anhydrase IX. J. Med. Chem. 2014, 57, 9435-9446. [CrossRef] [PubMed]

18. Genis, C.; Sippel, K.H.; Case, N.; Wengang Cao Avvaru, B.S.; Tartaglia, L.J.; Lakshmanan Govindasamy Tu, C.; AgbandjeMcKenna, M.; Silverman, D.N.; Rosser, C.J.; McKenna, R. Design of a carbonic anhydrase IX active-site mimic to screen inhibitors for possible anticancer properties. Biochemistry 2009, 48, 1322-1331. [CrossRef]

19. Pinard, M.A.; Boone, C.D.; Rife, B.D.; Supuran, C.T.; McKenna, R. Structural study of interaction between brinzolamide and dorzolamide inhibition of human carbonic anhydrases. Bioorg. Med. Chem. 2013, 21, 7210-7215. [CrossRef]

20. Čapkauskaitè, E.; Linkuvienè, V.; Smirnov, A.; Milinavičiūtè, G.; Timm, D.D.; Kasiliauskaitè, A.; Manakova, E.; Gražulis, S.; Matulis, D. Combinatorial Design of Isoform-Selective N-Alkylated Benzimidazole-Based Inhibitors of Carbonic Anhydrases. ChemistrySelect 2017, 2, 5360-5371. [CrossRef]

21. Smirnov, A.; Zubrienè, A.; Manakova, E.; Gražulis, S.; Matulis, D. Crystal structure correlations with the intrinsic thermodynamics of human carbonic anhydrase inhibitor binding. PeerJ 2018, 6, e4412. [CrossRef]

22. Matulis, D. Thermodynamics of the hydrophobic effect. III. Condensation and aggregation of alkanes, alcohols, and alkylamines. Biophys. Chem. 2001, 93, 67-82. [CrossRef]

23. Cimmperman, P.; Baranauskienè, L.; Jachimovičiūtè, S.; Jachno, J.; Torresan, J.; Michailovienè, V.; Matulienè, J.; Sereikaitė, J.; Bumelis, V.; Matulis, D. A Quantitative Model of Thermal Stabilization and Destabilization of Proteins by Ligands. Biophys. J. 2008, 95, 3222-3231. [CrossRef]

24. Leitans, J.; Kazaks, A.; Balode, A.; Ivanova, J.; Zalubovskis, R.; Supuran, C.T.; Tars, K. Efficient Expression and Crystallization System of Cancer-Associated Carbonic Anhydrase Isoform IX. J. Med. Chem. 2015, 58, 9004-9009. [CrossRef] [PubMed]

25. Sūdžius, J.; Baranauskienè, L.; Golovenko, D.; Matulienė, J.; Michailovienė, V.; Torresan, J.; Jachno, J.; Sukackaitė, R.; Manakova, E.; Gražulis, S.; et al. 4-[N-(Substituted 4-pyrimidinyl)amino]benzenesulfonamides as inhibitors of carbonic anhydrase isozymes I, II, VII, and XIII. Bioorg. Med. Chem. 2010, 18, 7413-7421. [CrossRef]

26. Jogaitè, V.; Zubrienè, A.; Michailovienė, V.; Gylytė, J.; Morkūnaitė, V.; Matulis, D. Characterization of human carbonic anhydrase XII stability and inhibitor binding. Bioorg. Med. Chem. 2013, 21, 1431-1436. [CrossRef]

27. Pantoliano, M.W.; Petrella, E.C.; Kwasnoski, J.D.; Lobanov, V.S.; Myslik, J.; Graf, E.; Carver, T.; Asel, E.; Springer, B.A.; Lane, P.; et al. High-density miniaturized thermal shift assays as a general strategy for drug discovery. J. Biomol. Screen 2001, 6, 429-440. [CrossRef]

28. Kazlauskas, E.; Petrauskas, V.; Paketurytė, V.; Matulis, D. Standard operating procedure for fluorescent thermal shift assay (FTSA) for determination of protein-ligand binding and protein stability. Eur. Biophys. J. 2021, 50, 373-379. [CrossRef] [PubMed]

29. Matulis, D.; Baumann, C.G.; Bloomfield, V.A.; Lovrien, R.E. 1-Anilino-8-naphthalene sulfonate as a protein conformational tightening agent. Biopolymers 1999, 49, 451-458. [CrossRef]

30. Baranauskienè, L.; Hilvo, M.; Matulienè, J.; Golovenko, D.; Manakova, E.; Dudutienè, V.; Michailovienè, V.; Torresan, J.; Jachno, J.; Parkkila, S.; et al. Inhibition and binding studies of carbonic anhydrase isozymes I, II and IX with benzimidazo[1,2c][1,2,3]thiadiazole-7-sulphonamides. J. Enzyme Inhib. Med. Chem. 2010, 25, 863-870. [CrossRef]

31. Falconer, R.J. Applications of isothermal titration calorimetry-The research and technical developments from 2011 to 2015 : Review of Isothermal Titration Calorimetry from 2011 to 2015. J. Mol. Recognit. 2016, 29, 504-515. [CrossRef]

32. Callies, O.; Daranas, A.H. Application of isothermal titration calorimetry as a tool to study natural product interactions. Nat. Prod. Rep. 2016, 33, 881-904. [CrossRef]

33. Linkuvienè, V.; Zubrienè, A.; Manakova, E.; Petrauskas, V.; Baranauskienè, L.; Zakšauskas, A.; Smirnov, A.; Gražulis, S.; Ladbury, J.E.; Matulis, D. Thermodynamic, kinetic, and structural parameterization of human carbonic anhydrase interactions toward enhanced inhibitor design. Q. Rev. Biophys. 2018, 51, 1-48. [CrossRef] [PubMed]

34. Snyder, P.W.; Mecinović, J.; Moustakas, D.T.; Thomas, S.W.; Harder, M.; Mack, E.T.; Lockett, M.R.; Héroux, A.; Sherman, W.; Whitesides, G.M. Mechanism of the hydrophobic effect in the biomolecular recognition of arylsulfonamides by carbonic anhydrase. Proc. Natl. Acad. Sci. USA 2011, 108, 17889-17894. [CrossRef]

35. Kabsch, W. XDS. Acta Crystallogr. Sect. D 2010, 66, 125-132. [CrossRef]

36. Battye, T.G.G.; Kontogiannis, L.; Johnson, O.; Powell, H.R.; Leslie, A.G.W. iMOSFLM: A new graphical interface for diffractionimage processing with MOSFLM. Acta Crystallogr. D Biol. Crystallogr. 2011, 67, 271-281. [CrossRef]

37. Evans, P. Scaling and assta quality. Acta Crystallogr. D Biol. Crystallogr. 2006, 62, 72-82. [CrossRef] [PubMed]

38. Bruker. SAINT (Version 8.18c). In Bruker Advanced X-ray Solutions; Bruker AXS: Madison, WI, USA, 2012.

39. Bruker. SADABS (Version 2.11). In Bruker Advanced X-ray Solutions; Bruker AXS: Madison, WI, USA, 2012.

40. Vagin, A.; Teplyakov, A. Molecular replacement with MOLREP. Acta Crystallogr. D Biol. Crystallogr. 2010, 66, 22-25. [CrossRef] 
41. Murshudov, G.N.; Skubák, P.; Lebedev, A.A.; Pannu, N.S.; Steiner, R.A.; Nicholls, R.A.; Winn, M.D.; Long, F.; Vagin, A.A. REFMAC5 for the refinement of macromolecular crystal structures. Acta Crystallogr. D Biol. Crystallogr. 2011, 67, $355-367$. [CrossRef] [PubMed]

42. Emsley, P.; Lohkamp, B.; Scott, W.G.; Cowtan, K. Features and development of it Coot. Acta Crystallogr. Sect. D 2010, 66, 486-501. [CrossRef] [PubMed]

43. Hanwell, M.D.; Curtis, D.E.; Lonie, D.C.; Vandermeersch, T.; Zurek, E.; Hutchison, G.R. Avogadro: An advanced semantic chemical editor, visualization, and analysis platform. J. Cheminform. 2012, 4, 17. [CrossRef] [PubMed]

44. Lebedev, A.A.; Young, P.; Isupov, M.N.; Moroz, O.V.; Vagin, A.A.; Murshudov, G.N. JLigand: A graphical tool for the CCP4 template-restraint library. Acta Crystallogr. D Biol. Crystallogr. 2012, 68, 431-440. [CrossRef] [PubMed]

45. Vagin, A.A.; Steiner, R.A.; Lebedev, A.A.; Potterton, L.; McNicholas, S.; Long, F.; Murshudov, G.N. REFMAC5 dictionary: Organization of prior chemical knowledge and guidelines for its use. Acta Crystallogr. D Biol. Crystallogr. 2004, 60, $2184-2195$. [CrossRef] 